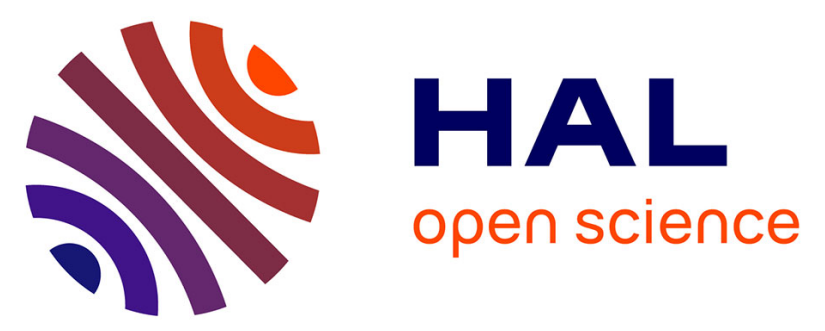

\title{
Hemisynthesis, crystal structure and inhibitory effect of sesquiterpenic thiosemicarbazones and thiazolidin-4-ones on the corrosion behaviour of stainless steel in $1 \mathrm{M} \mathrm{H} 2$ SO 4 solution
}

\author{
Abdoullah Bimoussa, Yassine Koumya, Abdesselam Abouelfida, Moulay \\ Youssef Ait Itto, Abdelaziz Benyaich, Olivier Mentré, El Mostafa Ketatni, \\ Aziz Auhmani, Abdelwahed Auhmani
}

\section{- To cite this version:}

Abdoullah Bimoussa, Yassine Koumya, Abdesselam Abouelfida, Moulay Youssef Ait Itto, Abdelaziz Benyaich, et al.. Hemisynthesis, crystal structure and inhibitory effect of sesquiterpenic thiosemicarbazones and thiazolidin-4-ones on the corrosion behaviour of stainless steel in $1 \mathrm{M} \mathrm{H} 2 \mathrm{SO} 4$ solution. Acta Crystallographica Section C : Structural Chemistry [2014-..], 2019, 75 (6), pp.623-632. 10.1107/S2053229619005631 . hal-03439521

\author{
HAL Id: hal-03439521 \\ https://hal.science/hal-03439521
}

Submitted on 22 Nov 2021

HAL is a multi-disciplinary open access archive for the deposit and dissemination of scientific research documents, whether they are published or not. The documents may come from teaching and research institutions in France or abroad, or from public or private research centers.
L'archive ouverte pluridisciplinaire HAL, est destinée au dépôt et à la diffusion de documents scientifiques de niveau recherche, publiés ou non, émanant des établissements d'enseignement et de recherche français ou étrangers, des laboratoires publics ou privés. 


\section{Hemisynthesis, crystal structure and inhibitory effect of se uiterpenic thiosemicarbazones and thiazolidin-4-ones on the corrosion behaviour of stainless steel in $1 \mathrm{M} \mathrm{H}_{2} \mathrm{SO}_{4}$ solution}

Keywords: essential oil; sesquiterpene hydrocarbon; hemisynthesis; thiosemicarbazone; thiazolidinone; crystal structure; computational chemistry; $\mathrm{C}-\mathrm{H} \cdots \mathrm{Cl}$ hydrogen bonding; corrosion; polarization; DFT; cyclic voltammetry.

CCDC reference: 1911992

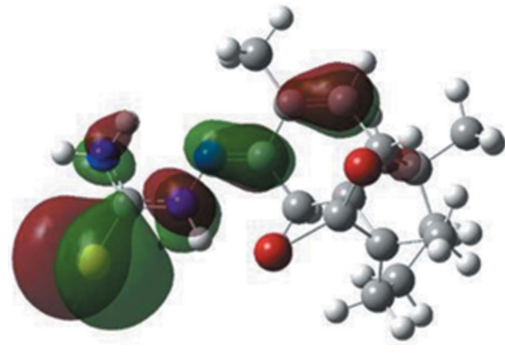

C 2019 International Union of Crystallography

\begin{abstract}
Abdoullah Bimoussa, ${ }^{\text {a }}$ Yassine Koumya, ${ }^{\text {b }}$ Abdesselam Abouelfida, ${ }^{\mathbf{b}}$ Moulay Youssef Ait Itto, ${ }^{a}$ Abdelaziz Benyaich, ${ }^{\mathrm{b}}$ Olivier Mentre, ${ }^{\mathrm{c}}$ El Mostafa Ketatni, ${ }^{\mathrm{d}}$ Aziz Auhmani $^{\text {a* }}$ and Abdelwahed Auhmani ${ }^{\mathrm{a}}$

a Laboratory of Organic Synthesis and Physico-Molecular Chemistry, Department of Chemistry, Faculty of Sciences Semlalia, PO Box 2390, Marrakech 40001, Morocco, 'baboratory of Physical Chemistry of Materials and Environment, Department of Chemistry, Faculty of Science Semlalia, Cadi Ayyad University, PO Box 2390, Marrakech, Morocco, 'Univ. Lille, CNRS, Centrale Lille, ENSCL, Univ. Artois, UMR 8181 - UCCS - Catalysis and Solid Chemistry Unit, F-59000 Lille, France, and 'Laboratory of Organic and Analytical Chemistry, University Sultan Moulay Slimane, Faculty of Science and Technology, PO Box 523, Beni-Mellal, Morocco. *Correspondence e-mail: a.auhmani@uca.ac.ma
\end{abstract}

Treatment of thiosemicarbazones prepared from sesquiterpenes with ethyl 2-bromoacetate in the presence of sodium acetate afforded the corresponding thiazolidin-4-ones. The structures of all the newly synthesized compounds were established by considering spectral and single-crystal X-ray diffraction data. The title compound, ethyl 2- $((Z)-2-\{(Z)-[(1 \mathrm{a} R, 5 \mathrm{a} R, 9 \mathrm{a} S)-1,1$-dichloro-1a,5,5,7-tetramethyl-1a,2,3,4,5,5a,8,9-octahydro- $1 H$-benzo[ $a$ ]cyclopropa[b][7]annulen-8-ylidene]hydrazono\}-4-oxothiazolidin-3-yl)acetate, $\mathrm{C}_{23} \mathrm{H}_{31} \mathrm{Cl}_{2} \mathrm{~N}_{3} \mathrm{O}_{3} \mathrm{~S}, \mathbf{5}$, crystallizes in the orthorhombic noncentrosymmetric space group $P 2_{1} 2_{1} 2_{1}$ with $Z=4$. Within the molecule in the crystal structure, the cyclohexene ring has an envelope conformation and the cycloheptane ring, to which it is fused, has a boat conformation. In the crystal, molecules are linked by $\mathrm{C}-\mathrm{H} \cdots \mathrm{Cl}$ hydrogen bonds forming chains propagating along the $b$-axis direction. The absolute configuration of the molecule in the crystal could be fully confirmed from anomalous dispersion effects [Flack parameter $=-0.04$ (2)]. Thiosemicarbazones $\mathbf{1}$ and $\mathbf{2}$ are efficient inhibitors for steel corrosion in $1 \mathrm{M} \mathrm{H}_{2} \mathrm{SO}_{4}$ solution, with a maximum efficiency of $92.28 \%$ at $10^{-3} M$. Furthermore, thiosemicarbazone compounds were found to be more efficient than thiazolidin4-one derivatives. In addition, cyclic voltammetry was used to characterize the tested molecules, as well to estimate the experimental value of the energy band gap.

\section{Introduction}

Thiazolidinones are an important class of heterocycles because a considerable number of them manifest diverse pharmacological properties, such as antifungal (Srivastava et al., 2005; Misra \& Patnayak, 1971), antibacterial (Bondock et al., 2006; Vicini et al., 2006; Bondock et al., 2007), antiviral (Rawal et al., 2005), anticancer (Ottana et al., 2005a,b; Gududuru et al., 2004; Pyo et al., 2001), anti-inflammatory (Vigorita et al., 2003; Ottana et al., 2002, 2005a,b), anthelmintic (Aries, 1974, 1975, 1976; Giraudon, 1972, 1973), antitubercular (Danila \& Radu, 1978, 1979; Zubenky et al., 1974, 1975), hypnotic (Chaudhary et al., 1975, 1976), anticonvulsant (Parmar et al., 1972; Shyam \& Tiwari, 1977) and cardiovascular effects (Suzuki et al., 1999; Nagar et al., 1973). Furthermore, it is documented that organic compounds containing $\pi$ electrons and heteroatoms, such as nitrogen, oxygen and sulfur, could be 
excellent as corrosion inhibitors (Gece, 2008; Idouhli et al., 2018a,b; Singh \& Chaudhary, 1996; Chaudhary et al., 2007). Thus, recently, Idouhli et al. $(2018 a, b)$ reported that monoterpenic thiosemicarbazones are efficient inhibitors for steel corrosion in $1 \mathrm{M} \mathrm{HCl}$. Mourya et al. (2013) also investigated a thiosemicarbazone derivative as a corrosion inhibitor of mild steel in $1 \mathrm{~N} \mathrm{HCl}$ and $1 \mathrm{~N} \mathrm{H}_{2} \mathrm{SO}_{4}$. The inhibitive action of some 1,3,4-thiadiazole derivatives against corrosion was investigated by Lebrini et al. (2007), Blajiev \& Hubin (2004) and Bentiss et al. (2007). In continuation of our investigations of the hemisynthesis of new compounds with added value using sesquiterpene hydrocarbons extracted from the essential oil of Cedrus atlantica, we describe herein the hemisynthesis, the crystal structure and the effect of newly synthesized thiazolidin-4-one and thiosemicarbazone molecules on the corrosion behaviour of stainless steel. The quantum chemical calculations were also employed to link between the inhibition efficiency and the molecular properties of the tested compounds.

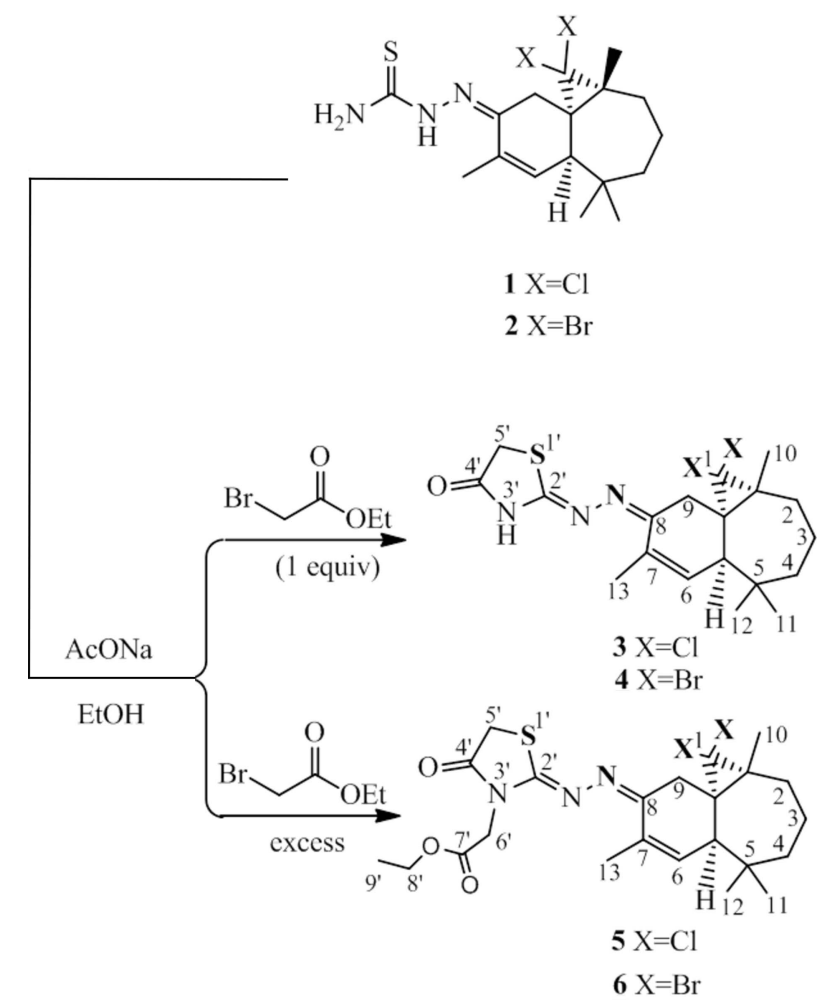

Scheme 1

\section{Experimental}

IR spectra were recorded on a Bruker Vertex 70 spectrophotometer using potassium bromide discs in the frequency range 4000-400 $\mathrm{cm}^{-1} .{ }^{1} \mathrm{H}$ and ${ }^{13} \mathrm{C}$ NMR spectra were recorded on a Bruker Avance $300(75) \mathrm{MHz}$ spectrometer. Chemical shifts $(\delta, \mathrm{ppm})$ were reported with reference to $\mathrm{SiMe}_{4}\left({ }^{1} \mathrm{H}\right)$. Melting points were determined with a Kofler bench apparatus and are uncorrected. Elemental analyses were taken with an Elementar Vario EL-III Analyzer. All solvents were dried and distilled before use. Column chromatography was performed on silica gel 60 (70-230 mesh, Merck). Thin-layer chromatography (TLC) was carried out on Merck $0.2 \mathrm{~mm}$ silica gel 60 F254 analytical aluminium plates.

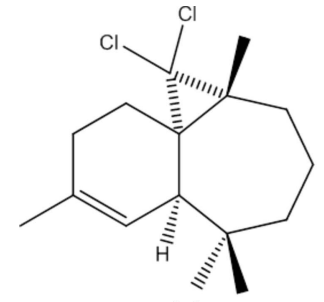

(a)

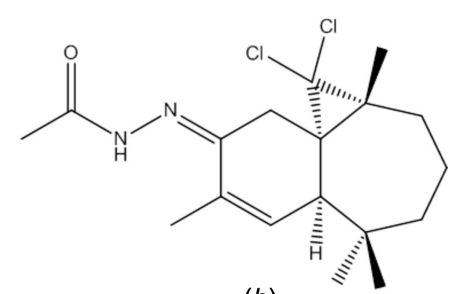

(b)

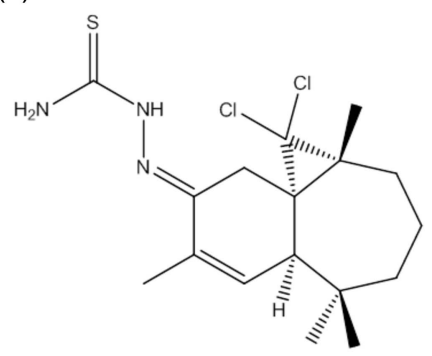

(c)

Scheme 2

\subsection{Hemisynthesis}

2.1.1. General procedure for the preparation of thiosemicarbazone 2. A mixture of enone $(1 \mathrm{mmol})$ dissolved in ethanol $(20 \mathrm{ml})$, thiosemicarbazide $(2 \mathrm{mmol})$ and a few drops of $\mathrm{H}_{2} \mathrm{SO}_{4}$ were refluxed with magnetic stirring for 2 to $3 \mathrm{~h}$. The yellow precipitate which formed was removed by filtration and recrystallized from EtOH solution to give the thiosemicarbazone $(Z)-2-[(1 \mathrm{a} R, 5 \mathrm{a} R, 9 \mathrm{a} S)$-1,1-dibromo-1a,5,5,7-tetramethyl1a,2,3,4,5,5a,8,9-octahydro-1 $H$-benzo $[a]$ cyclopropa $[b][7]$ annulen-8(9H)-ylidene]hydrazinecarbothioamide, 2.

Analytical data for 2: yield $65 \%$; m.p. $183-184{ }^{\circ} \mathrm{C}$; IR (KBr) $v_{\max } / \mathrm{cm}^{-1}: 3409\left(\mathrm{NH}_{2}\right), 3147(\mathrm{NH}), 2925(\mathrm{C}=\mathrm{C}), 1592$ $(\mathrm{C}=\mathrm{N}), 1290(\mathrm{C}=\mathrm{S}), 1066(\mathrm{C}-\mathrm{N}) ;{ }^{1} \mathrm{H}$ NMR $(300 \mathrm{MHz}$, $\left.\mathrm{CDCl}_{3}\right): \delta 8.75,7.28,6.44\left(3 \mathrm{H}, \mathrm{NH}_{2}\right.$ and $\left.\mathrm{NH}\right), 6.24(1 \mathrm{H}, d, J=$ $7.22 \mathrm{~Hz}), 0.84(3 \mathrm{H}, s), 1.01(3 \mathrm{H}, s), 1.96(3 \mathrm{H}, s), 1.82(3 \mathrm{H}, s), 2.5$ $(1 \mathrm{H}, d, J=7.9 \mathrm{~Hz}), 2.62(2 \mathrm{H}, \mathrm{AB}$ system, $J=18.2 \mathrm{~Hz}) ;{ }^{13} \mathrm{C}$ NMR (75 MHz, CDCl $)$ ) 60.44 (C-1), 33.74 (C-1a), 29.67 (C-2), 38.79 (C-3), 41.33 (C-4), 29.6 (C-5), 47.91 (C-5a), 135.84 (C-6), 133.22 (C-7), 147.37 (C-8), 21.35 (C-9), 38.79 (C-9a), 22.64 (C-10), 18.63 (C-11), 18.03 (C-12), $29.67(\mathrm{C}-13), 179.02(\mathrm{C}=\mathrm{S})$. Analysis calculated (\%) for $\mathrm{C}_{17} \mathrm{H}_{25} \mathrm{Br}_{2} \mathrm{~N}_{3} \mathrm{~S}$ : C 44.07, H 5.44, N 9.07, S 6.92; found: C 44.04, H 5.37, N 9.03, S 6.89.

2.1.2. General method for the hemisynthesis of thiazolidin4-ones 3, 4, 5 and 6. A mixture of thiosemicarbazone $(1 \mathrm{mmol})$, ethyl 2-bromoacetate $(1 \mathrm{mmol}, 167 \mathrm{mg})$ in the cases of $\mathbf{3}$ and $\mathbf{4}$ (an excess of ethyl 2-bromoacetate in the cases of $\mathbf{5}$ and 6), and anhydrous sodium acetate $(4.5 \mathrm{mmol}, 369 \mathrm{mg})$ in ethanol $(30 \mathrm{ml})$ was stirred under reflux for $1 \mathrm{~h}$ until none of the starting materials was detected using TLC. The solvent was removed under reduced pressure. The residue was dissolved in water $(100 \mathrm{ml})$ and extracted with ethyl acetate $(3 \times 50 \mathrm{ml})$. The organic layer was dried over $\mathrm{Na}_{2} \mathrm{SO}_{4}$ and concentrated in vacuo. The residue was purified by flash chromatography on silica gel using $n$-hexane-ethyl acetate $(92: 8 v / v)$ as eluent. 
Analytical data for $(Z)-2-\{(Z)-[(1 \mathrm{a} R, 5 \mathrm{a} R, 9 \mathrm{a} S)$-1,1-dichloro1a,5,5,7-tetramethyl-1a, $2,3,4,5,5 \mathrm{a}, 8,9$-octahydro- $1 H$-benzo $[a]$ cyclopropa[b][7]annulen-8-ylidene]hydrazono\}thiazolidin-4one, 3. Yield 52\%; IR ( $\mathrm{KBr}) v_{\max } / \mathrm{cm}^{-1}: 3418(\mathrm{NH}), 2925$ $(\mathrm{C}=\mathrm{C}), 1724(\mathrm{C}=\mathrm{O}), 1599(\mathrm{C}=\mathrm{N}), 1554(\mathrm{C}=\mathrm{N}), 1022$ $(\mathrm{C}-\mathrm{N}) ;{ }^{1} \mathrm{H}$ NMR $\left(300 \mathrm{MHz}, \mathrm{CDCl}_{3}\right): \delta 0.86(3 \mathrm{H}, s), 1.01(3 \mathrm{H}$, $s), 1.20(3 \mathrm{H}, s), 2.00(3 \mathrm{H}, s), 2.46(1 \mathrm{H}, d, J=6.23 \mathrm{~Hz}), 2.7(2 \mathrm{H}$, AB system, $J=18.3 \mathrm{~Hz}), 6.23(1 \mathrm{H}, d, J=7.9 \mathrm{~Hz}), 3.75(2 \mathrm{H}, s)$, $9.5(\mathrm{NH}, s) ;{ }^{13} \mathrm{C}$ NMR $\left(75 \mathrm{MHz}, \mathrm{CDCl}_{3}\right): \delta 77.53(\mathrm{C}-1), 33.08$ (C-1a), 29.90 (C-2), 29.70 (C-3), 38.77 (C-4), 46.05 (C-5a), 33.49 (C-5), 136.91 (C-6), 133.99 (C-7), 164.01 (C-8), 21.09 (C-9), 21.33 (C-9a), 14.16 (C-10), 17.95 (C-11), 16.05 (C-12), 29.70 (C-13), 161.09 (C-2'), 32.35 (C-5'), 173.67 (C-4'). Analysis calculated (\%) for $\mathrm{C}_{19} \mathrm{H}_{25} \mathrm{Cl}_{2} \mathrm{~N}_{3} \mathrm{OS}$ : C 55.07, $\mathrm{H}$ 6.08, N 10.14, S 7.74; found: C 54.99, H 6.03, N 10.04, S 7.69.

Analytical data for $(Z)-2-\{(Z)-[(1 \mathrm{a} R, 5 \mathrm{a} R, 9 \mathrm{a} S)-1,1$-dibromo1a,5,5,7-tetramethyl-1a, 2,3,4,5,5a,8,9-octahydro- $1 H$-benzo[ $a]$ cyclopropa[b][7]annulen-8-ylidene]hydrazono\}thiazolidin-4one, 4. Yield $62 \%$; m.p. $194-195{ }^{\circ} \mathrm{C}$; IR ( $\left.\mathrm{KBr}\right) v_{\max } / \mathrm{cm}^{-1}: 3467$ $(\mathrm{NH}), 2927(\mathrm{C}=\mathrm{C}), 1721(\mathrm{C}=\mathrm{O}), 1621(\mathrm{C}=\mathrm{N}), 1458(\mathrm{C}=\mathrm{N})$, $1038(\mathrm{C}-\mathrm{N}) ;{ }^{1} \mathrm{H}$ NMR $\left(300 \mathrm{MHz}, \mathrm{CDCl}_{3}\right): \delta 0.8(3 \mathrm{H}, s), 0.89$ $(3 \mathrm{H}, s), 1.29(3 \mathrm{H}, s), 2.02(3 \mathrm{H}, s), 2.61(2 \mathrm{H}, \mathrm{AB}$ system, $J=$ $18.4 \mathrm{~Hz}), 6.23(d, 1 \mathrm{H}, J=8.10 \mathrm{~Hz}), 3.76(2 \mathrm{H}, s), 8.9(1 \mathrm{H}, s) ;{ }^{13} \mathrm{C}$ NMR $\left(75 \mathrm{MHz}, \mathrm{CDCl}_{3}\right): \delta 58.57$ (C-1), 33.26 (C-1a), 29.73 (C-2), 28.83 (C-3), 38.66 (C-4), 34.57 (C-5), 48.47 (C-5a), 136.32 (C-6), 134.30 (C-7), 163.43 (C-8), 21.41 (C-9), 38.66 (C-9a), 14.06 (C-10), 18.21 (C-11), 17.82 (C-12), 28.84 (C-13), $160.79\left(\mathrm{C}-2^{\prime}\right), 33.03\left(\mathrm{C}-5^{\prime}\right), 173.42\left(\mathrm{C}-4^{\prime}\right)$. Analysis calculated (\%) for $\mathrm{C}_{19} \mathrm{H}_{25} \mathrm{Br}_{2} \mathrm{~N}_{3} \mathrm{OS}$ : C 45.34, H 5.01, N 8.35, S 6.37\%; found: C 45.31, $\mathrm{H} 4.96, \mathrm{~N}$ 8.26, S 6.30.

Analytical data for ethyl 2- $((Z)-2-\{(Z)-[(1 \mathrm{a} R, 5 \mathrm{a} R, 9 \mathrm{a} S)-1,1-$ dichloro-1a,5,5,7-tetramethyl-1a,2,3,4,5,5a,8,9-octahydro- $1 H$ benzo[ $a]$ cyclopropa[ $b][7]$ annulen-8-ylidene]hydrazono\}-4-oxothiazolidin-3-yl)acetate, 5. Yield $46 \%$; m.p. $252-253^{\circ} \mathrm{C}$; IR $(\mathrm{KBr}) v_{\max } / \mathrm{cm}^{-1}: 3446(\mathrm{NH}), 2924(\mathrm{C}=\mathrm{C}), 1753(\mathrm{C}=\mathrm{O}), 1728$ $(\mathrm{C}-\mathrm{O}), 1563(\mathrm{C}=\mathrm{N}), 1624(\mathrm{C}=\mathrm{N}), 1342(\mathrm{C}-\mathrm{O}), 1017(\mathrm{C}-$ $\mathrm{N}) ;{ }^{1} \mathrm{H}$ NMR $\left(300 \mathrm{MHz}, \mathrm{CDCl}_{3}\right): \delta 0.78(3 \mathrm{H}, s), 0.80(3 \mathrm{H}, s), 1.20$ $(3 \mathrm{H}, s), 1.49(3 \mathrm{H}, t, J=7.03 \mathrm{~Hz}), 1.93(3 \mathrm{H}, s), 2.68(2 \mathrm{H}, \mathrm{AB}$ system, $J=18.3 \mathrm{~Hz}), 3.75(2 \mathrm{H}, s), 4.49(2 \mathrm{H}, q, J=7.03 \mathrm{~Hz}), 4.44$ $(2 \mathrm{H}, \mathrm{AB}$ system, $J=16.6 \mathrm{~Hz}), 6.11(1 \mathrm{H}, d, J=7.9 \mathrm{~Hz}), 2.41(1 \mathrm{H}$, $d, J=7.9 \mathrm{~Hz}) ;{ }^{13} \mathrm{C}$ NMR $\left(75 \mathrm{MHz}, \mathrm{CDCl}_{3}\right): \delta 78.36(\mathrm{C}-1), 30.18$ (C-1a), 31.92 (C-2), 29.71 (C-3), 29.36 (C-4), 34.72 (C-5), 46.13 (C-5a), 136.61 (C-6), 134.13 (C-7), 162.18 (C-8), 21.37 (C-9), 22.37 (C-9a), 22.69 (C-10), 17.88 (C-11), 16.03 (C-12), 29.36 (C-13), 160.25 (C-2'), 173.85 (C-4'), 46.16 (C-5'), 43.96 (C-6'), $166.60\left(\mathrm{C}-7^{\prime}\right), 61.67\left(\mathrm{C}-8^{\prime}\right), 17.88\left(\mathrm{C}-9^{\prime}\right)$. Analysis calculated (\%) for $\mathrm{C}_{23} \mathrm{H}_{31} \mathrm{Cl}_{2} \mathrm{~N}_{3} \mathrm{O}_{3} \mathrm{~S}$ : C 55.20, $\mathrm{H}$ 6.24, N 8.40, $\mathrm{S}$ 6.41; found: C 55.11, H 6.19, N 8.36, S 6.39.

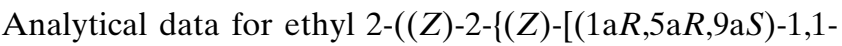
dibromo-1a,5,5,7-tetramethyl-1a,2,3,4,5,5a,8,9-octahydro- $1 H$ benzo[ $a]$ cyclopropa[ $b][7]$ annulen-8-ylidene]hydrazono\}-4-oxothiazolidin-3-yl)acetate, 6 . Yield $44 \%$; IR $(\mathrm{KBr}) v_{\max } / \mathrm{cm}^{-1}$ : $3447(\mathrm{NH}), 2931(\mathrm{C}=\mathrm{C}), 1731(\mathrm{C}=\mathrm{O}), 1608(\mathrm{C}-\mathrm{O}), 1461$ $(\mathrm{C}=\mathrm{N}), 1623(\mathrm{C}=\mathrm{N}), 1205(\mathrm{C}-\mathrm{O}), 1030(\mathrm{C}-\mathrm{N}) ;{ }^{1} \mathrm{H}$ NMR $\left(300 \mathrm{MHz}, \mathrm{CDCl}_{3}\right): \delta 0.87(3 \mathrm{H}, s), 1.01(3 \mathrm{H}, s), 1.36(3 \mathrm{H}, s)$, $1.55(3 \mathrm{H}, t, J=7.07 \mathrm{~Hz}), 2.02(3 \mathrm{H}, s), 2.69(2 \mathrm{H}, \mathrm{AB}$ system, $J=$ $18.4 \mathrm{~Hz}), 2.47(1 \mathrm{H}, d, J=8.18 \mathrm{~Hz}), 3.85(2 \mathrm{H}, s), 4.21(2 \mathrm{H}, q, J=$
Table 1

Experimental details.

\begin{tabular}{|c|c|}
\hline \multicolumn{2}{|l|}{ Crystal data } \\
\hline Chemical formula & $\mathrm{C}_{23} \mathrm{H}_{31} \mathrm{Cl}_{2} \mathrm{~N}_{3} \mathrm{O}_{3} \mathrm{~S}$ \\
\hline$M_{\mathrm{r}}$ & 500.47 \\
\hline Crystal system, space group & Orthorhombic, $P 2_{1} 2_{1} 2_{1}$ \\
\hline Temperature $(\mathrm{K})$ & 299 \\
\hline$a, b, c(\AA)$ & $\begin{array}{l}10.2769(7), 12.2445(7), \\
20.0804(13)\end{array}$ \\
\hline$V\left(\AA^{3}\right)$ & $2526.8(3)$ \\
\hline$Z$ & 4 \\
\hline Radiation type & Мо $K \alpha$ \\
\hline$\mu\left(\mathrm{mm}^{-1}\right)$ & 0.37 \\
\hline Crystal size $(\mathrm{mm})$ & $0.34 \times 0.21 \times 0.11$ \\
\hline \multicolumn{2}{|l|}{ Data collection } \\
\hline Diffractometer & Bruker DUO APEXII CCD \\
\hline Absorption correction & $\begin{array}{l}\text { Multi-scan (SADABS; Bruker, } \\
\text { 2012) }\end{array}$ \\
\hline$T_{\min }, T_{\max }$ & $0.710,0.746$ \\
\hline $\begin{array}{l}\text { No. of measured, independent and } \\
\text { observed }[I>2 \sigma(I)] \text { reflections }\end{array}$ & $58280,5789,4306$ \\
\hline$R_{\text {int }}$ & 0.056 \\
\hline$(\sin \theta / \lambda)_{\max }\left(\AA^{-1}\right)$ & 0.650 \\
\hline \multicolumn{2}{|l|}{ Refinement } \\
\hline$R\left[F^{2}>2 \sigma\left(F^{2}\right)\right], w R\left(F^{2}\right), S$ & $0.038,0.089,1.03$ \\
\hline No. of reflections & 5789 \\
\hline No. of parameters & 294 \\
\hline $\mathrm{H}$-atom treatment & $\mathrm{H}$-atom parameters constrained \\
\hline$\Delta \rho_{\max }, \Delta \rho_{\min }\left(\mathrm{e} \AA^{-3}\right)$ & $0.26,-0.19$ \\
\hline Absolute structure & $\begin{array}{l}\text { Flack } x \text { determined using } 1538 \\
\text { quotients }\left[\left(I^{+}\right)-\left(I^{-}\right)\right] / \\
{\left[\left(I^{+}\right)+\left(I^{-}\right)\right](\text {Parsons } \text { et al., } 2013)}\end{array}$ \\
\hline Absolute structure parameter & $-0.04(2)$ \\
\hline
\end{tabular}

Computer programs: DUO in APEX2 (Bruker, 2012), SAINT (Bruker, 2012) SHELXS2014 (Sheldrick, 2008), SHELXL2014 (Sheldrick, 2015), ORTEP-3 for Windows (Farrugia, 2012) and DIAMOND (Brandenburg \& Putz, 2012).

$7.07 \mathrm{~Hz}), 4.51(2 \mathrm{H}, \mathrm{AB}$ system, $J=16.6 \mathrm{~Hz}), 6.22(1 \mathrm{H}, d, J=$ $8.18 \mathrm{~Hz}) ;{ }^{13} \mathrm{C}$ NMR $\left(75 \mathrm{MHz}, \mathrm{CDCl}_{3}\right): \delta 61.76(\mathrm{C}-1), 34.51$ (C-1a), 32.50 (C-2), 28.72 (C-3), 38.65 (C-4), 33.24 (C-5), 43.94 (C-5a), 136.28 (C-6), 134.31 (C-7), 162.00 (C-8), 21.46 (C-9), 38.51 (C-9a), 21.10 (C-10), 18.18 (C-11), 17.19 (C-12), 29.79

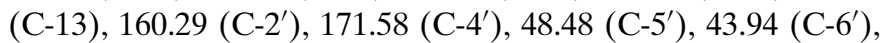
$166.63\left(\mathrm{C}-7^{\prime}\right), 61.76\left(\mathrm{C}-8^{\prime}\right), 17.91\left(\mathrm{C}-9^{\prime}\right)$. Analysis calculated (\%) for $\mathrm{C}_{23} \mathrm{H}_{31} \mathrm{Br}_{2} \mathrm{~N}_{3} \mathrm{O}_{3} \mathrm{~S}$ : C 46.87, $\mathrm{H}$ 5.30, N 7.13, S 5.44; found: C 46.82, H 5.26, N 7.09, S 5.38.

\subsection{Structure solution and refinement}

The crystallographic data and experimental details for $\mathbf{5}$ are summarized in Table $1 . \mathrm{H}$ atoms were positioned geometrically and refined using a riding model, with $\mathrm{C}-\mathrm{H}=0.93-$ $1.00 \AA$ and $U_{\text {iso }}(\mathrm{H})=1.5 U_{\text {eq }}(\mathrm{C})$ for methyl $\mathrm{H}$ atoms or $1.2 U_{\text {eq }}(\mathrm{C})$ otherwise. The absolute structure was determined reliably based on the value of the Flack parameter [-0.04 (2)].

2.3. Electrochemical measurements and theoretical calculations

2.3.1. Material and methods. Potentiodynamic polarization measurements were carried out using voltalab potentiostat model PGZ301 with a three-electrode electrochemical cell and were recorded at a constant sweep rate of $1 \mathrm{mV} \mathrm{s}^{-1}$ in the potential range from -600 to $0 \mathrm{mV}$ versus SCE. An electr 
of $0.96 \mathrm{~cm}^{2}$ exposed area was used as the working electrode (WE), together with a platinum counter-electrode (CE) and a saturated calomel electrode (SCE) as the reference electrode. The stainless steel specimens employed in the electrochemical cell have the following chemical composition: $69.10 \% \mathrm{Fe}$, $17.58 \% \mathrm{Cr}, 9.01 \% \mathrm{Ni}, 2.19 \% \mathrm{C}, 0.54 \% \mathrm{Si}$ and $0.39 \% \mathrm{Ti}$. Cyclic voltammetry experiments were carried out using a threeelectrode cell consisting of a platinum working electrode, a platinum counter-electrode and a saturated calomel electrode as the reference electrode using a scan rate of $100 \mathrm{mV} \mathrm{s}^{-1}$. The tested molecules were dissolved in $10^{-3} M$ acetonitrile. The supporting electrolyte was $0.2 \mathrm{M}$ tetrabutylammonium perchlorate in anhydrous acetonitrile $\left(\mathrm{CH}_{3} \mathrm{CN}\right)$.

2.3.2. Quantum chemical calculations. In order to determine the effect of the inhibitor structure on the corrosion process, density functional theory (DFT) was used to gain more insight into the molecular properties of the different tested derivatives. DFT quantum calculations have been carried out for the optimization of the molecules using the B3LYP function with a 6-31G(d) basis set (Becke, 1988; Lee et al., 1988). The molecules were built with the Gauss View software (Version 09W; Frisch et al., 2009). The detailed calculation method for the quantum chemical parameters has been described elsewhere (Klapper et al., 2013).

\section{Results and discussion}

\subsection{Synthesis}

Several protocols for the preparation of thiazolidin-4-ones are used. Thus, a variety of these compounds was developed by using conventional one- and two-pot syntheses (Singh et al., 1981; Cunico et al., 2007). Another method for the synthesis of thiazolidin-4-ones is the use of a task-specific ionic liquid as the synthetic equivalent of an ionic liquid phase matrix (FragaDubreuil \& Bazureau, 2003). Holmes reported solution and polymer-supported methods to prepare thiazolidin-4-ones (Holmes et al., 1995). This synthesis was performed by a onepot three-component condensation under microwave irradiation (Dandia et al., 2006; Desai \& Mistry, 2006). Finally, an encoded thiazolidin-4-one library on a solid phase was reported by Maclean et al. (2004). In our approach to the synthesis of novel thiazolidin-4-ones, we tried to devise a process that could use a natural product thiosemicarbazone to react with ethyl 2-bromoacetate, as shown in Scheme 1.

Thus, treatment of thiosemicarbazone 1 (Auhmani et al., 1999, 2002; Ourhriss et al., 2005) or thiosemicarbazone 2 with an equivalent of ethyl 2-bromoacetate in the presence of sodium acetate afforded the nonsubstituted thiazolidinones (Z)-2-\{(Z)-[(1aR,5aR,9a $S)$-1,1-dichloro-1a,5,5,7-tetramethyl1a,2,3,4,5,5a,8,9-octahydro- $1 H$-benzo $[a]$ cyclopropa[ $b][7]$ annulen-8-ylidene]hydrazono $\}$ thiazolidin-4-one, $\mathbf{3}$, and $(Z)-2-\{(Z)$ [(1aR,5a $R, 9 \mathrm{a} S)$-1,1-dibromo-1a,5,5,7-tetramethyl-1a,2,3,4,5,5a,8,9-octahydro- $1 H$-benzo[ $a]$ cyclopropa[b][7]annulen-8-ylidene]hydrazono\}thiazolidin-4-one, 4 . They were purified by flash chromatography with hexane as eluent and isolated as yellow liquids. The ${ }^{1} \mathrm{H}$ NMR spectrum of $\mathbf{3}$ showed a characteristic

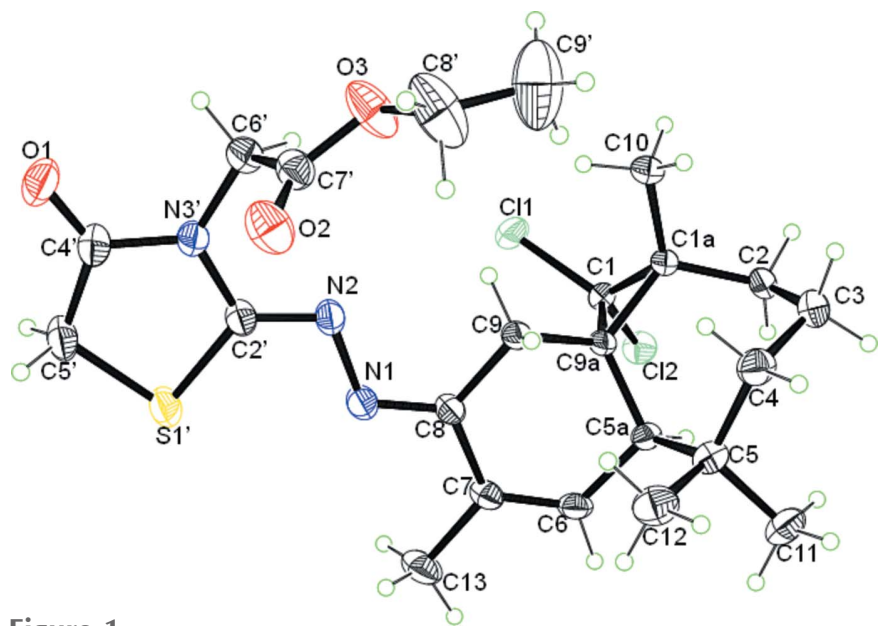

Figure 1

The molecular structure of the title molecule, 5, showing the atomlabelling scheme and $30 \%$ probability displacement ellipsoids.

broad peak at $9.5 \mathrm{ppm}$ assignable to the $\mathrm{NH}$ proton, followed by a doublet $(J=7.9 \mathrm{~Hz})$ at $6.23 \mathrm{ppm}$ for the $\mathrm{H}-6$ proton and an additional singlet at $3.74 \mathrm{ppm}$ for $\mathrm{H}-5^{\prime}$. The methylene protons on position 9 are magnetically non-equivalent and therefore display an $\mathrm{AB}$ system $(J=18.3 \mathrm{~Hz})$ centred at $2.7 \mathrm{ppm}$. However, under similar conditions, but with an excess of ethyl 2-bromoacetate, thiosemicarbazones $\mathbf{1}$ and $\mathbf{2}$

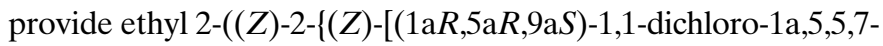
tetramethyl-1a,2,3,4,5,5a,8,9-octahydro- $1 H$-benzo[ $[a]$ cyclopropa[b][7]annulen-8-ylidene]hydrazono\}-4-oxothiazolidin-3-yl)acetate, 5, and ethyl 2-( $(Z)-2-\{(Z)-[(1 \mathrm{a} R, 5 \mathrm{a} R, 9 \mathrm{a} S)-1,1-$ dibromo1a,5,5,7-tetramethyl-1a, 2,3,4,5,5a,8,9-octahydro-1 $H$-benzo[ $a]$ cyclopropa[b][7]annulen-8-ylidene]hydrazono\}-4-oxothiazolidin-3yl)acetate, $\mathbf{6}$, in good yields. The structures of substituted thiazolidin-4-ones 5 and $\mathbf{6}$ were further characterized by FTIR and ${ }^{1} \mathrm{H}$ and ${ }^{13} \mathrm{C}$ NMR spectroscopies. In the ${ }^{1} \mathrm{H}$ NMR spectrum of $\mathbf{5}$, we note the absence of the characteristic signal of $\mathrm{NH}$ and the appearance of the signals of the acetate group. Thus, the corresponding methylene and methyl protons of the ethoxy group exhibit, respectively, a quadruplet $(J=7.03 \mathrm{~Hz})$ at $4.49 \mathrm{ppm}$ and a triplet $(J=7.03 \mathrm{~Hz})$ at $1.49 \mathrm{ppm}$. The methylene proton at the 6 '-position appears as an $\mathrm{AB}$ system $(J=16.6 \mathrm{~Hz})$ at $4.44 \mathrm{ppm}$. The structure of 5 was confirmed by single-crystal X-ray diffraction analysis.

\subsection{Crystal structure of the thiazolidin-4-one derivative}

The compound is built from two fused six- and sevenmembered rings which bear a dichlorocyclopropane group. An additional thiazolidinone hydrazone is linked to ethoxy-oxoethylidene units (Fig. 1). In the molecule, there are three chiral $\mathrm{C}$ atoms: $\mathrm{C} 1 \mathrm{a}$ and $\mathrm{C} 5 \mathrm{a}$ exhibits an $R$ configuration and C9a exhibits an $S$ configuration. The dihedral angle between the mean planes through the six- and seven-membered rings is $59.8(2)^{\circ}$. The three-membered ring $(\mathrm{Cl} / \mathrm{Cla} / \mathrm{C} 9 \mathrm{a})$ is nearly perpendicular to the mean plane of the six-membered ring (C5a/C6-C9/C9a), making a dihedral angle of $87.5(2)^{\circ}$.

The six-membered cyclohexylidene ring has an approximate envelope conformation, with the puckering parameters $Q=$ 
Table 2

Selected geometric parameters $\left(\AA,{ }^{\circ}\right)$ for 5 (reported here) and a-c (reported previously).

\begin{tabular}{lllll}
\hline Bond lengths & $\mathbf{5}$ & $\mathbf{a}^{*}$ & $\mathbf{b}^{* *}$ & $\mathbf{c}^{* * *}$ \\
\hline Cl1-C1 & $1.768(3)$ & $1.757(3)$ & $1.763(6)$ & $1.769(2)$ \\
C12-C1 & $1.768(3)$ & $1.762(3)$ & $1.766(6)$ & $1.761(2)$ \\
N1-C8 & $1.287(4)$ & - & $1.283(7)$ & $1.288(2)$ \\
C6-C7 & $1.331(5)$ & $1.318(4)$ & $1.342(8)$ & $1.326(3)$ \\
C7-C8 & $1.472(4)$ & $1.486(4)$ & $1.474(8)$ & $1.472(2)$ \\
C8-C9 & $1.509(4)$ & $1.511(4)$ & $1.512(7)$ & $1.504(2)$ \\
Cl1-C1-Cl2 & $108.1(2)$ & $107.6(2)$ & $108.2(3)$ & $108.8(1)$ \\
C7-C8-C9 & $118.6(3)$ & $114.8(2)$ & $118.2(4)$ & $119.6(2)$ \\
C6-C7-C8 & $119.9(3)$ & $121.4(3)$ & $120.2(4)$ & $119.0(2)$ \\
N1-C8-C7 & $117.0(3)$ & - & $116.3(4)$ & $116.3(2)$ \\
N1-C8-C9 & $124.3(3)$ & - & $125.4(5)$ & $124.2(2)$ \\
\hline
\end{tabular}

References: (*) Auhmani et al. (1999); (**) Benharref et al. (2016); (***) Ourhriss et al. (2005).

0.457 (3) $\AA$, spherical polar angle $\theta=55.6(5)^{\circ}$ and $\varphi=$ $292.1(5)^{\circ}$, whereas the seven-membered ring displays a boat conformation, with a total puckering amplitude $Q 2=1.139$ (4) and $Q 3=0.035$ (4) (Cremer \& Pople, 1975).

Another point of interest is the comparison of the molecular structure of $\mathbf{5}$ with that of parent compound a (Auhmani et al., 1999) and also with b (Benharref et al., 2016) and $\mathbf{c}$ (Ourhriss et al., 2005) (see Scheme 2). The $\mathrm{C}-\mathrm{Cl}$ bond lengths [average 1.767 (3) $\AA$ ] are in good agreement with the $\mathrm{Cl}-\mathrm{C}$ bond length of 1.764 (6) $\AA$ reported for the related compounds (Table 2 and Scheme 2). The main difference between the conformations of these molecules is observed for the cyclohexene ring (between envelope and half-chair for $\mathbf{a}$, half-chair for $\mathbf{b}$ and screw-boat for $\mathbf{c}$ ).

As expected, the thiazolidine ring and all the atoms attached to it (plane $\mathrm{A}=\mathrm{S}^{\prime} / \mathrm{C}^{\prime} / \mathrm{N}^{\prime} / \mathrm{C}^{\prime} / \mathrm{C}^{\prime} / \mathrm{N} 2 / \mathrm{N} 1 / \mathrm{O} 1 / \mathrm{C}^{\prime}$ ) are roughly coplanar, with an r.m.s. deviation of $0.05 \AA$. Its

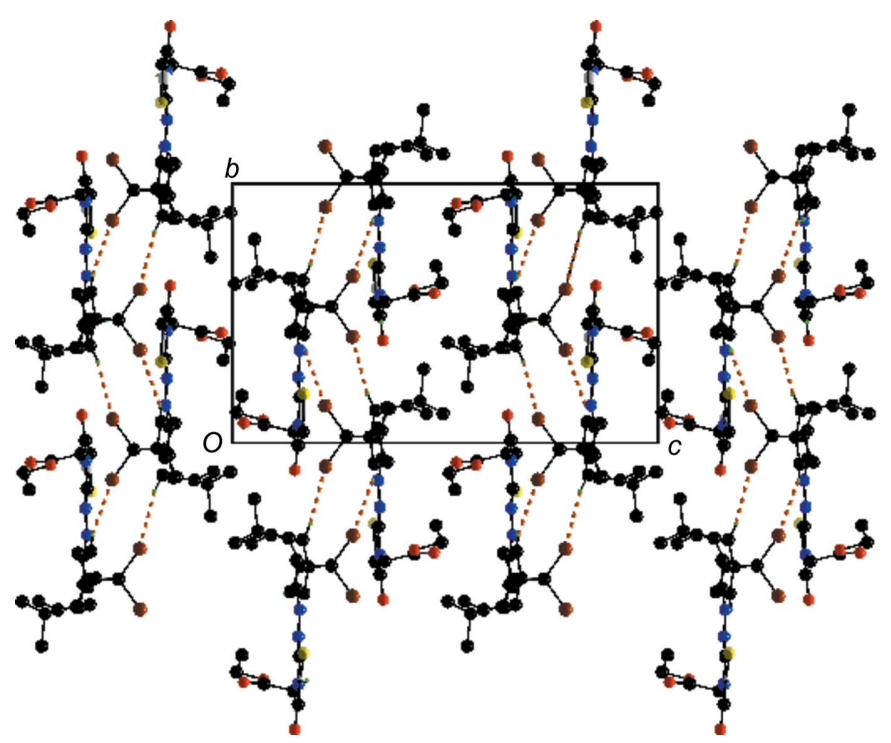

Figure 2

Packing and hydrogen-bonding interactions of the title compound viewed along the $b$ axis. For clarity, only the $\mathrm{H}$ atoms involved in the hydrogen bonds (dashed lines) have been included.
Table 3

Comparison of main bond lengths $(\AA)$ and $\mathrm{C}=\mathrm{N}-\mathrm{N}=\mathrm{C}$ torsions angles $\left.{ }^{\circ}\right)$ in the title compound and related structures.

\begin{tabular}{llllllll}
\hline $\mathrm{N} 1-\mathrm{N} 2$ & $\mathrm{C} 2^{\prime}-\mathrm{N} 2$ & $\mathrm{~N} 1-\mathrm{C} 8$ & $\mathrm{~S}^{\prime}-\mathrm{C} 2^{\prime}$ & $\mathrm{N} 3^{\prime}-\mathrm{C} 2^{\prime}$ & $\mathrm{C}=\mathrm{N}-\mathrm{N}=\mathrm{C}$ & Reference \\
\hline $1.413(4)$ & $1.275(5)$ & $1.288(4)$ & $1.744(4)$ & $1.383(4)$ & $-174.7(3)$ & $a$ \\
$1.417(3)$ & $1.269(3)$ & $1.291(3)$ & $1.756(3)$ & $1.380(3)$ & $173.8(3)$ & $b$ \\
$1.406(2)$ & $1.277(2)$ & $1.287(2)$ & $1.769(2)$ & $1.386(2)$ & $179.0(2)$ & $c$ \\
$1.405(3)$ & $1.274(3)$ & $1.286(4)$ & $1.756(3)$ & $1.398(3)$ & $-168.9(2)$ & $d$ \\
$1.407(2)$ & $1.281(2)$ & $1.291(2)$ & $1.761(2)$ & $1.392(2)$ & $179.4(2)$ & $e$ \\
$1.414(2)$ & $1.278(2)$ & $1.278(2)$ & $1.749(2)$ & $1.367(2)$ & $-177.3(2)$ & $f$ \\
$1.417(7)$ & $1.256(7)$ & $1.268(8)$ & $1.759(5)$ & $1.412(8)$ & $-177.6(8)$ & $g$ \\
$1.410(6)$ & $1.279(7)$ & $1.279(7)$ & $1.767(5)$ & $1.364(7)$ & $174.9(7)$ & $h$ \\
\hline
\end{tabular}

References: (a) this study; (b) Gautam \& Chaudhary (2015); (c) Hassan et al. (2017); (d) N'ait Ousidi et al. (2017); (e) Mague et al. (2014); ( $f$ ) Ramachandran et al. (2009); ( $g$ ) Gupta \& Chaudhary (2013); (h) Gautam et al. (2013).

mean plane makes a dihedral angle of $57.1(1)^{\circ}$ with the mean plane of the three-fused-ring system $(\mathrm{C} 1 / \mathrm{C} 1 \mathrm{a} / \mathrm{C} 2 / \mathrm{C} 3 / \mathrm{C} 4 / \mathrm{C} 5 /$ $\mathrm{C} 5 \mathrm{a} / \mathrm{C} 6 / \mathrm{C} 7 / \mathrm{C} 8 / \mathrm{C} 9 / \mathrm{C} 9 \mathrm{a})$.

A comparison of the main $\mathrm{C}-\mathrm{N}, \mathrm{N}-\mathrm{N}$ and $\mathrm{C}-\mathrm{S}$ distances in the title compound and the structures formed by thiazolidine ring substituted by a hydrazone linked to a cyclohexyl ring as the main skeleton (Table 3 ) shows a good correlation: within the $\mathrm{C}=\mathrm{N}-\mathrm{N}=\mathrm{C}$ fragment, the double bonds are located on $\mathrm{C}=\mathrm{N}$ and the $\mathrm{N}-\mathrm{N}$ distance is that of a single bond corresponding to a hydrazono group. The $\mathrm{C}=\mathrm{N}-\mathrm{N}=\mathrm{C}$ torsion angles (Table 3) indicate that, in each case, the four atoms are nearly planar.

In the crystal, molecules are linked via $\mathrm{C}-\mathrm{H} \cdots \mathrm{Cl}$ hydrogen bonds, forming chains propagating along the $b$-axis direction (Table 4 and Fig. 2).

\subsection{Electrochemical and theoretical studies}

3.3.1. Potentiodynamic polarization. Fig. 3 shows the potentiodynamic polarization curves of stainless steel (SS) in sulfuric acid in the absence and presence of the different synthesized molecules. The derived electrochemical parameters, such as the corrosion potential $E_{\text {corr }}$, the corrosion current density $i_{\text {corr }}$ and the inhibition efficiency $\eta(\%)$, are listed in Table 5. The inhibition efficiency values were calculated by:

$$
\eta(\%)=\left[\left(i_{\text {corr }}-i_{\text {corr }}^{\prime} / i_{\text {corr }}\right)\right] \times 100,
$$

where $i_{\text {corr }}$ and $i_{\text {corr }}^{\prime}$ are corrosion density without and with inhibitor, respectively.

It is clearly observed that thiosemicarbazones $\mathbf{1}$ and $\mathbf{2}$ both have reduced the corrosion current density and the corrosion potential was found to tend to more positive values with the addition of the inhibitor. The shift in the corrosion potential

Table 4

Hydrogen-bond geometry $\left(\AA,^{\circ}\right)$.

\begin{tabular}{lllll}
\hline$D-\mathrm{H} \cdots A$ & $D-\mathrm{H}$ & $\mathrm{H} \cdots A$ & $D \cdots A$ & $D-\mathrm{H} \cdots A$ \\
\hline $\mathrm{C} 10-\mathrm{H} 10 A \cdots \mathrm{Cl} 2^{\mathrm{i}}$ & 0.96 & 2.79 & $3.557(3)$ & 137 \\
$\mathrm{C} 2-\mathrm{H} 2 B \cdots \mathrm{Cl} 1^{\mathrm{ii}}$ & 0.97 & 2.81 & $3.661(3)$ & 147
\end{tabular}

Symmetry codes: (i) $-x+2, y-\frac{1}{2},-z+\frac{1}{2}$; (ii) $-x+2, y+\frac{1}{2},-z+\frac{1}{2}$. 
Table 5

Tafel parameters and corresponding inhibition efficiency derived from potentiodynamic polarization curves.

\begin{tabular}{llll}
\hline Inhibitor & $E_{\text {corr }}(\mathrm{mV}$ versus $\mathrm{SCE})$ & $i_{\text {corr }}\left(\mathrm{mA} \mathrm{cm}^{-2}\right)$ & $\eta(\%)$ \\
\hline Blank & -378.7 & 305.9 & - \\
$\mathbf{1}$ & -330.3 & 112.8 & 63.12 \\
$\mathbf{3}$ & -327.7 & 129.9 & 57.53 \\
$\mathbf{5}$ & -369.4 & 202.5 & 33.80 \\
$\mathbf{2}$ & -376.2 & 23.6 & 92.28 \\
$\mathbf{4}$ & -327.8 & 187.4 & 38.73 \\
$\mathbf{6}$ & -311.3 & 132.2 & 56.78 \\
\hline
\end{tabular}

for both compounds is less than $85 \mathrm{mV}$ with respect to the blank (Li et al., 2012). Thus, both thiosemicarbazones act as mixed-type inhibitors. It should also be mentioned that both the anodic dissolution reaction and cathodic hydrogen evolution have been affected by the addition of the thiosemicarbazone. This trend may be explained by the fact that the addition of the inhibitor may block simultaneously the cathodic and anodic active sites (Patel et al., 2013). The same behaviour has been observed with the thiazolidin-4-one derivatives; all these derivatives acted as mixed-type inhibitors. It can also be seen from Table 5 that thiazolidin-4-one derivatives do not show a good performance with respect to the thiosemicarbazone derivatives. In the case of the thiosemicarbazones, the maximum inhibition efficiency reached is $92 \%$ and was attained with the addition of $10^{-3} M$ of compound 2. However, the maximum inhibition efficiency for the thiazolidin-4-one derivatives does not exceed $57 \%$. The order of the inhibition efficiency $\eta(\%)$ was found to be: $\mathbf{2}>\mathbf{1}>$ $\mathbf{3}>\mathbf{6}>\mathbf{4}>\mathbf{5}$ (Table 5). These results reveal that thiosemicarbazone derivatives act as good corrosion inhibitors for SS corrosion in sulfuric acid; also, the inhibition efficiency depends greatly on the molecular structure of these derivatives.

3.3.2. Cyclic voltammetry measurements.. For insights into the electrochemical activity of the tested molecules, as well as experimental calculations of the energy levels, the cyclic voltammetry measurements were performed in the wide potential range of -2000 to $2000 \mathrm{mV}$ versus SCE. Fig. 4 shows that the cyclic voltammograms of the thiosemicarbazone molecules are different than those of the thiazolidin-4-one derivatives and display three anodic peaks and two cathodic peaks. However, the depicted electrochemical behaviour of the thiazolidin-4-one compounds is different due to the blocked electrochemical reactivity owing to the addition of new substituents to the molecular structure. All the cyclic voltammograms show an irreversible electrochemical process
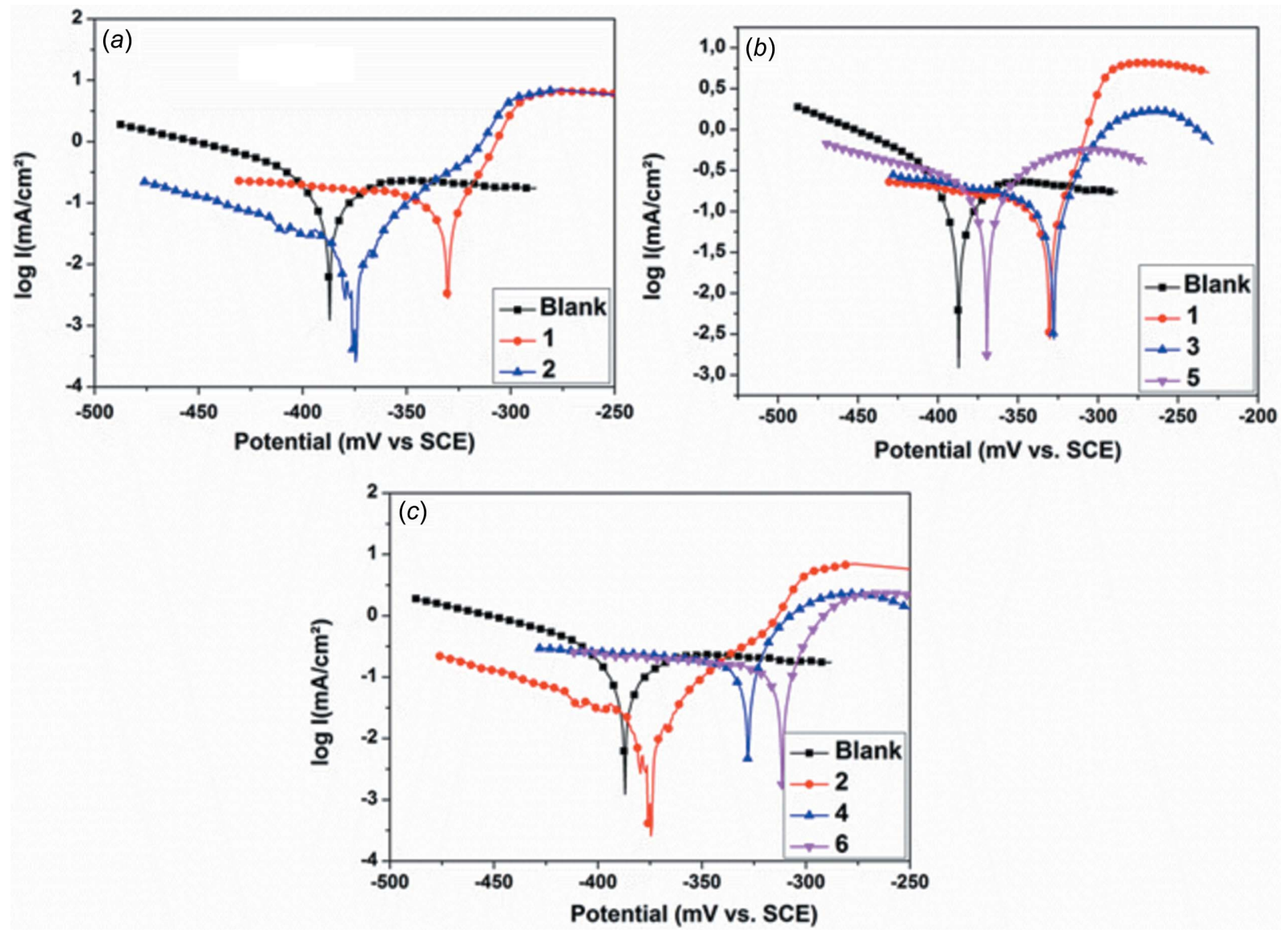

Figure 3

Potentiodynamic polarization curves of SS in sulfuric acid in the absence and presence of $10^{-3} M$ of different synthesized molecules, for (a) thiosemicarbazone derivatives, $(b)$ thiazolidin-4-one derivatives having chloride functional groups and $(c)$ thiazolidin-4-one derivatives having bromide functional groups. 
Table 6

Cyclic voltammetry parameters for the different tested molecules in a solution of $0.2 \mathrm{M} \mathrm{Et}_{4} \mathrm{NClO}_{4} /$ acetonitrile at $100 \mathrm{mV} \mathrm{s}^{-1}$.

\begin{tabular}{lrrrrr}
\hline Molecule & $E_{\text {ox }}^{\text {onset }}$ & $E_{\text {HOMO }}$ & $E_{\text {red }}^{\text {onset }}$ & $E_{\text {LUMO }}$ & $\Delta E$ \\
\hline $\mathbf{1}$ & 0.235 & -5.035 & 0.102 & -4.902 & 0.133 \\
$\mathbf{2}$ & -0.235 & -4.565 & -0.324 & -4.476 & 0.089 \\
$\mathbf{3}$ & 0.537 & -5.337 & 0.235 & -5.035 & 0.302 \\
$\mathbf{4}$ & 0.271 & -5.071 & 0.129 & -4.929 & 0.142 \\
$\mathbf{5}$ & 0.572 & -5.372 & 0.226 & -5.026 & 0.346 \\
$\mathbf{6}$ & 0.182 & -4.982 & 0.031 & -4.831 & 0.151 \\
\hline
\end{tabular}

because of the large separation between the anodic and cathodic peaks. The HOMO and LUMO energy levels of the different studied molecules were calculated from the onset oxidation potential ( $E_{\mathrm{ox}}^{\text {onset }}$ ) and the onset reduction potential $\left(E_{\mathrm{red}}^{\text {onset }}\right)$ using the following equations (Das et al., 2015; Li et al., 2011).

$$
\begin{aligned}
& E_{\mathrm{HOMO}}=-E_{\mathrm{Ox}}^{\text {onset }}-4.8(1) \\
& E_{\mathrm{LUMO}}=-E_{\mathrm{red}}^{\text {onset }}-4.8(2)
\end{aligned}
$$

The redox potentials, HOMO energy, LUMO energy and band gap for the different molecules are summarized in Table 6 . The obtained results indicate that thiosemicarbazones $\mathbf{1}$ and $\mathbf{2}$ have the lowest band gap, which is in good agreement with the band gap deduced from the theoretical approach.
Table 7

Molecular properties of the thiosemicarbazone and thiazolidin-4-one derivatives calculated using DFT at the B3LYP/6-31G(d) basis set.

\begin{tabular}{lcccccc}
\hline Molecule & $\mathbf{1}$ & $\mathbf{2}$ & $\mathbf{4}$ & $\mathbf{6}$ & $\mathbf{3}$ & $\mathbf{5}$ \\
\hline$E_{\text {HOMO }}$ & -0.201 & -0.203 & -0.216 & -0.212 & -0.217 & -0.213 \\
$E_{\mathrm{LUMO}}$ & -0.051 & -0.053 & -0.054 & -0.053 & -0.055 & -0.053 \\
$\Delta E$ & 0.150 & 0.150 & 0.162 & 0.158 & 0.161 & 0.159 \\
$\eta$ & 0.075 & 0.075 & 0.081 & 0.079 & 0.080 & 0.079 \\
$\Delta E_{\mathrm{T}}$ & -0.01875 & -0.018 & -0.020 & -0.0198 & -0.0202 & -0.0198 \\
$\Delta N$ & 45.821 & 45.651 & 42.307 & 43.294 & 42.393 & 43.150 \\
Dipole & 7.295 & 6.696 & 3.738 & 3.834 & 3.881 & 4.085 \\
$\quad$ moment & & & & & & \\
\hline
\end{tabular}

Also, the experimental gap energy is roughly in the same order of magnitude when compared to the theoretical value.

3.3.3. Quantum chemical calculations. Generally, molecules having lower absolute values of the energy band gap ( $\left.\Delta E=\left|E_{\mathrm{LUMO}}-E_{\mathrm{HOMO}}\right|\right)$ exhibit higher inhibition efficiencies since the energy to remove an electron from the last occupied orbital will be lower (Lebrini et al., 2007). Table 7 summarizes the molecular properties of the molecules calculated using DFT at the B3LYP/6-31G(d) basis set. It is clear that the value of $\Delta E$ for the different studied molecules increases in the order $\mathbf{1}<\mathbf{2}<\mathbf{6}<\mathbf{5}<\mathbf{3}<\mathbf{4}$; this indicates that compounds $\mathbf{1}$ and $\mathbf{2}$ exhibit higher inhibition efficiencies. The dipole moment is another parameter of the electronic distribution in a molecule
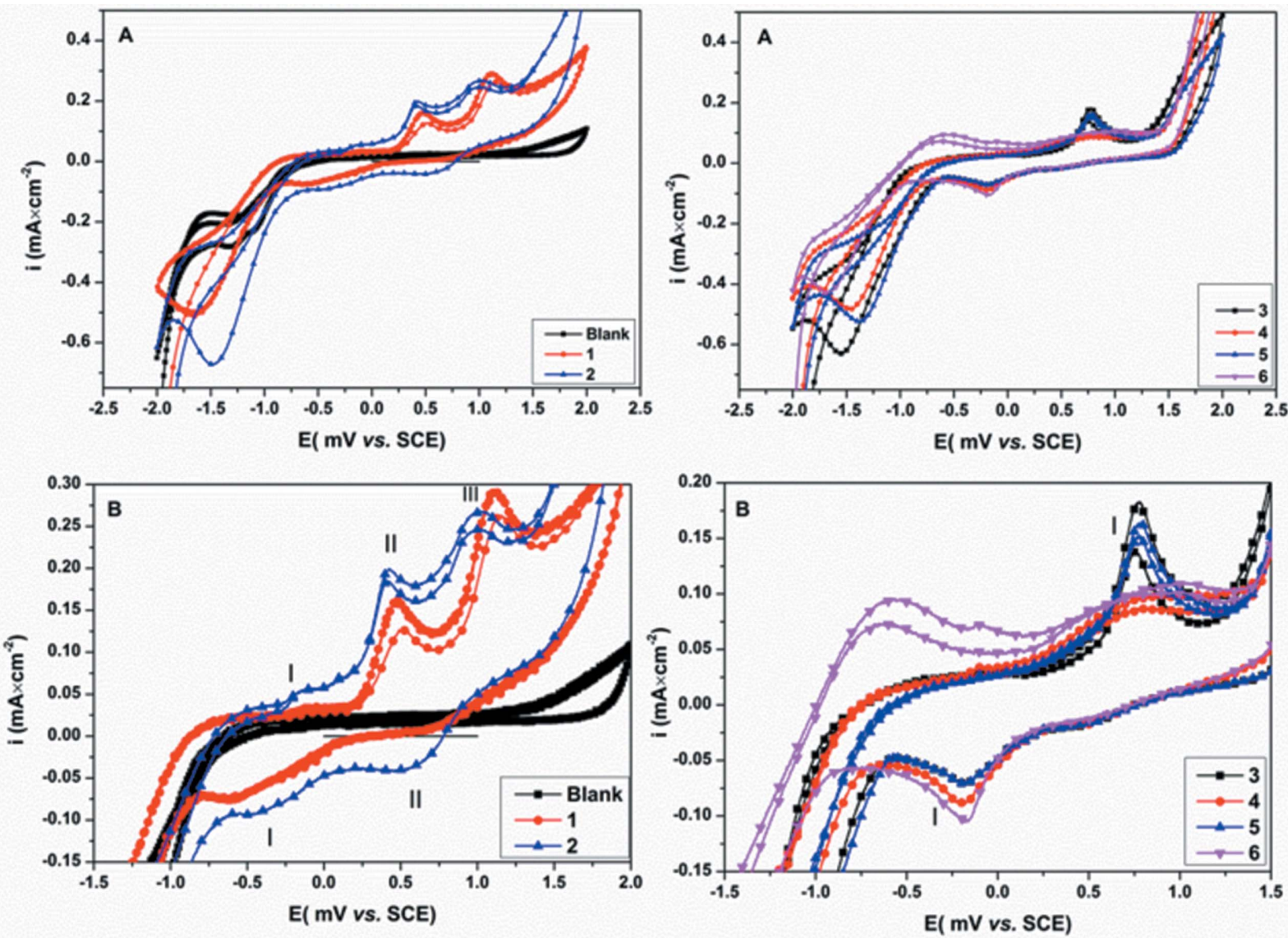

Figure 4

Cyclic voltammograms of (a) $10^{-3} M$ thiosemicarbazone compounds and (b) $10^{-3} M$ thiazolidin-4-one derivatives in a solution of $0.2 M$ Et $_{4} \mathrm{NClO}_{4} /$ acetonitrile at $100 \mathrm{mV} \mathrm{s}^{-1}$. 


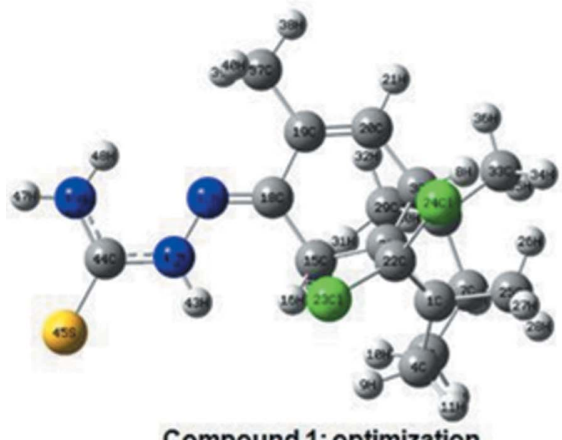

Compound 1: optimization

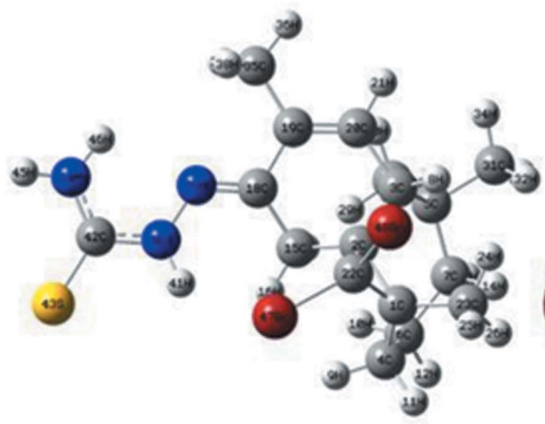

Compound 2: optimization
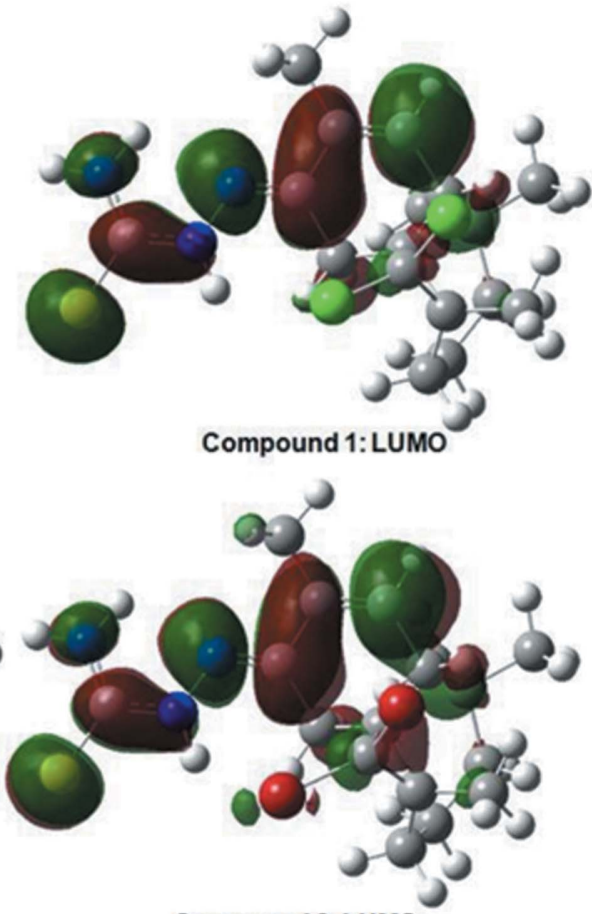

Compound 2: LUMO

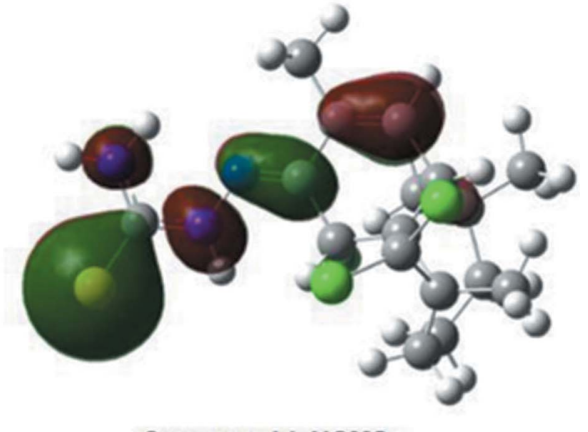

Compound 1: HOMO

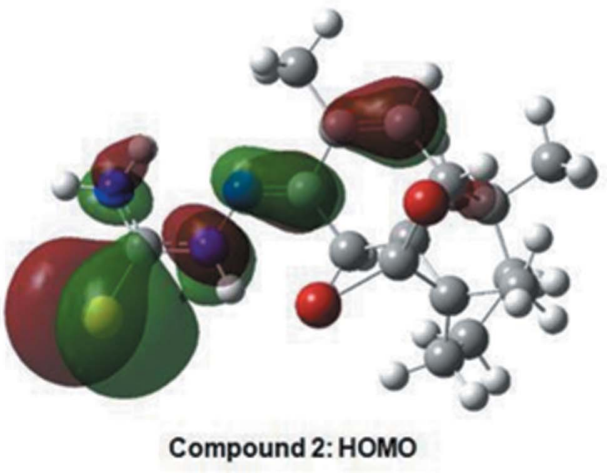

Figure 5

The optimized molecule and the HOMO and LUMO levels for thiosemicarbazone compounds $\mathbf{1}$ and 2 calculated with the B3LYP/6-31G(d) basis set.

and is a measure of the polarity of a polar covalent bond (BenHmamou et al., 2015). Many authors report that the inhibition efficiency increases with an increase in the dipolemoment parameter which depends on the type and nature of the molecules considered, yet others suggested the opposite (Al-sabagh et al., 2013). In general, it can be stated that the adsorption mode of the molecules depends holistically upon the involved polar functional groups interacting with a stainless steel surface, as well as the surface charge and the solution-dissolved ions. In fact, there is a lack of agreement in the literature on the correlation between dipole moment and the inhibition efficiency (Al-sabagh et al., 2013). It is clearly seen
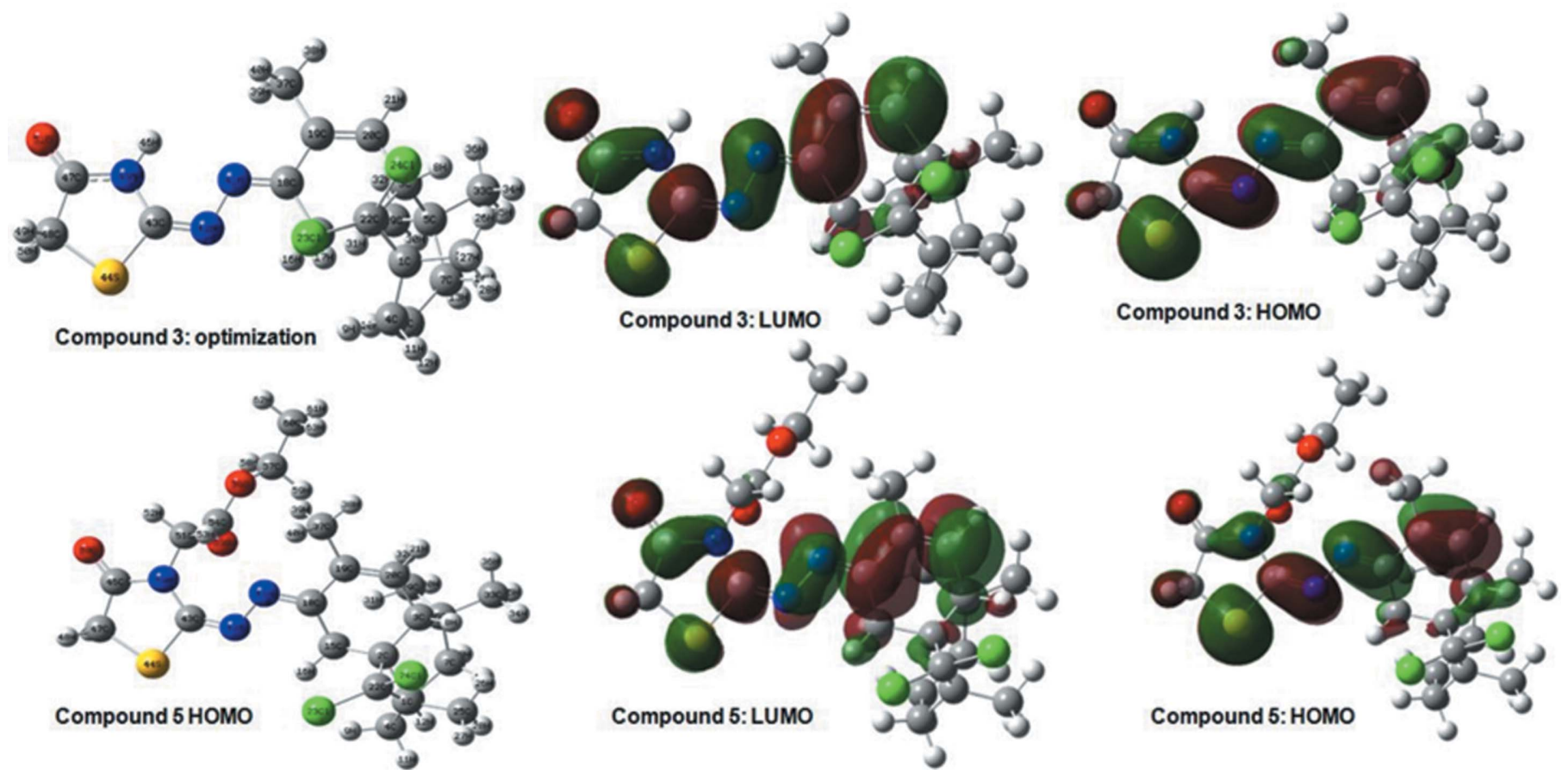

Figure 6

The optimized molecule and the HOMO and LUMO levels for thiazolidin-4-one compounds 3 and $\mathbf{5}$ calculated with the B3LYP/6-31G(d) basis set. 

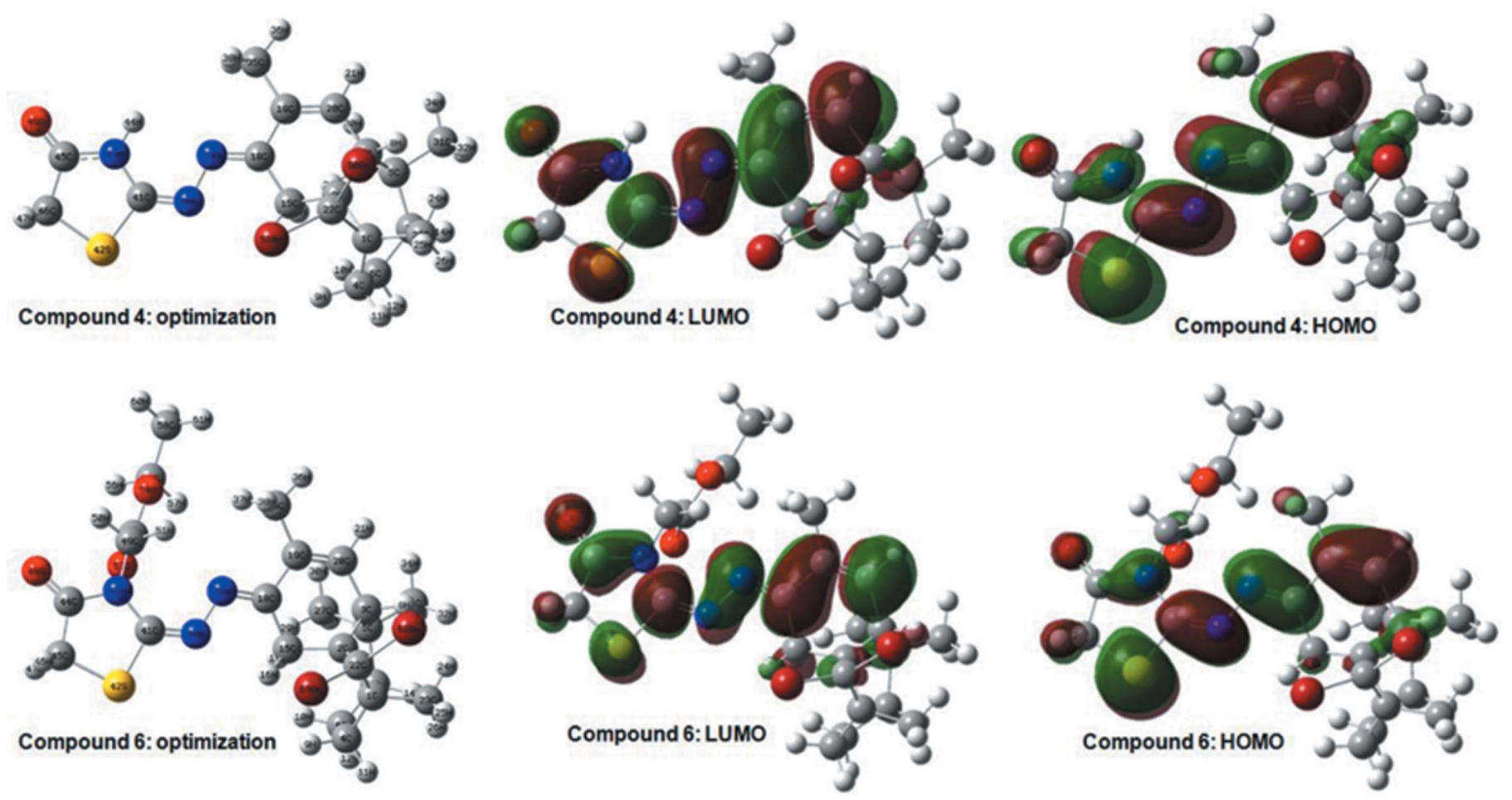

Figure 7

The optimized molecule and the HOMO and LUMO levels for thiazolidin-4-one compounds 4 and $\mathbf{6}$ calculated with the B3LYP/6-31G(d) basis set.

that the dipole moment of the investigated molecules follows the order $\mathbf{1}>\mathbf{2}>\mathbf{5}>\mathbf{3}>\mathbf{6}>\mathbf{4}$ and the thiosemicarbazone compounds have higher values of the dipole moment with respect to the thiazolidin-4-one derivatives. The fractions of electrons transferred from inhibitor to metal surface were also determined (Table 7). According to Lukovits et al. (2001), if $\Delta N<3.6$, the inhibition efficiency of a molecule increases with the increasing electron-donating ability at the metal surface. In the present case, the value of $\Delta N$ for all the tested derivatives is much higher than 3.6 , which means that the increase in inhibition efficiency is not only due to the electron-donating ability of the inhibitor. From Table 7, we see that the values of the hardness for all molecules are positive $(\eta>0)$ and $\Delta E_{\mathrm{T}}<$ 0 . This indicates that both donation and back-donation processes are responsible for the observed inhibition efficiency for all molecules (Klapper et al. 2013). Figs. 5, 6 and 7 show the HOMO, LUMO and optimized structures of the different studied molecules. It is clearly seen that both the HOMO and LUMO are predominantly made up of S and $\mathrm{N}$ atoms, as well as the $\mathrm{C}$ atoms implied in the conjugated system. The obtained theoretical results are in agreement with the experimental findings as the thiosemicarbazones have shown a good inhibition efficiency compared to the thiazolidin-4-one molecules.

\section{Conclusion}

In summary, we have prepared a new thiosemicarbazone and four new thiazolidin-4-ones using sesquiterpene hydrocarbon extracted from Cedrus atlantica. The substituted thiazolidin-4ones were obtained by reacting the corresponding thio- semicarbazones with an excess of ethyl 2-bromoacetate. However, with an equivalent of ethyl 2-bromoacetate, we obtained the corresponding nonsubstituted thiazolidin-4-one. The compounds were characterized spectroscopically and compound $\mathbf{5}$ was also characterized by single-crystal X-ray diffraction. The results of the potentiodynamic polarization measurements indicated that all tested molecules act as mixedtype inhibitors. Thiosemicarbazone $\mathbf{2}$ showed a maximum inhibition efficiency of $92 \%$ at $10^{-3} \mathrm{M}$. The analysis of the different compounds has revealed that the thiosemicarbazone compounds could be more efficient than the thiazolidin-4-one derivatives. Quantum chemical calculations support the experimental findings. Based on the molecular properties of the different molecules, both donation and back donation are responsible for the inhibition efficiency. Cyclic voltammetry studies demonstrate that the thiosemicarbazone molecules have the lowest energy band gap, which substantiates the theoretical data.

\section{Acknowledgements}

The X-ray diffractometers are funded by Region NPDC, FEDER, CNRS and MESR.

\section{References}

Al-sabagh, A. M., Nasser, N. M., Migahed, M. A., Eissa, A. M. F. \& Mahmoud, T. (2013). Egypt. J. Pet. 22, 101-116.

Aries, R. (1974). Fr. Patent 2186 245; Chem. Abstr. 81, 140869.

Aries, R. (1975). Fr. Patent 2190431.

Aries, R. (1976). Chem. Abstr. 84, 35329

Auhmani, A., Kossareva, E., Eljamili, H., Réglier, M., Pierrot, M. \& Benharref, A. (2002). Synth. Commun. 32, 699-707. 
Auhmani, A., Kossareva, E., Lassaba, E., Réglier, M., Pierrot, M. \& Benharref, A. (1999). Acta Cryst. C55, IUC9900055.

Becke, A. D. (1988). Phys. Rev. A, 38, 3098-3100.

Benharref, A., Oukhrib, A., Ait Elhad, M., Daran, J. C. \& Berraho, M. (2016). IUCrData, 1, x160554.

BenHmamou, D., Salghi, R., Zarrouk, A., Zarrok, H., Touzani, R., Hammouti, B. \& El Assyry, A. (2015). J. Environ. Chem. Eng. 3, 2031-2041.

Bentiss, F., Lebrini, M., Lagrenée, M., Traisnel, M., Elfarouk, A. \& Vezin, H. (2007). Electrochim. Acta, 52, 6865-6872.

Blajiev, O. \& Hubin, A. (2004). Electrochim. Acta, 49, 2761-2770.

Bondock, S., Khalifa, W. \& Fadda, A. A. (2006). Synth. Commun. 36, 1601-1612.

Bondock, S., Khalifa, W. \& Fadda, A. A. (2007). Eur. J. Med. Chem. 42, 948-954.

Brandenburg, K. \& Putz, H. (2012). DIAMOND. Crystal Impact GbR, Bonn, Germany.

Bruker (2012). APEX2, SAINT and SADABS. Bruker AXS Inc., Madison, Wisconsin, USA.

Chaudhary, M., Parmar, S. S., Chaudhary, S. K., Chaturvedi, A. K. \& Rama Sastry, B. V. (1976). J. Pharm. Sci. 65, 443-446.

Chaudhary, R. S., Tyagi, D. K., Rani, M. \& Kumar, A. (2007). J. Sci. Ind. Res. 66, 47-51.

Chaudhary, S. K., Verma, M., Chaturvedi, A. K. \& Parmar, S. S. (1975). J. Pharm. Sci. 64, 614-617.

Cremer, D. \& Pople, J. A. (1975). J. Am. Chem. Soc. 97, 1354-1358.

Cunico, W., Gomes, C. R. B., Ferreira, M. D. L., Capri, L. R., Soares, M. \& Wardell, S. M. S. V. (2007). Tetrahedron Lett. 48, 6217-6220.

Dandia, A., Singh, R., Khaturia, S., Me-rienne, C., Morgantc, G. \& Loupyd, A. (2006). Bioorg. Med. Chem. 14, 2409-2417.

Danila, G. \& Radu, C. (1978). Rev. Med. Chir. 82, 127-130.

Danila, G. \& Radu, C. (1979). Chem. Abstr. 90, 33767.

Das, J., Siram, R. B. K., Cahen, D., Rybtchinski, B. \& Hodes, G. (2015). J. Mater. Chem. A, 3, 20305-20312.

Desai, K. R. \& Mistry, K. (2006). Indian J. Chem. Sect. B, 45, 17621766.

Farrugia, L. J. (2012). J. Appl. Cryst. 45, 849-854.

Fraga-Dubreuil, J. \& Bazureau, J. P. (2003). Tetrahedron, 59, 61216130.

Frisch M. J., et al. (2009). GAUSSIAN09. Revision A.01. Gaussian Inc., Wallingford, CT, USA. http://www.gaussian.com.

Gautam, D. \& Chaudhary, R. P. (2015). J. Mol. Struct. 1080, 137144.

Gautam, D., Gautam, P. \& Chaudhary, R. P. (2013). Heterocycl. Commun. 19, 43-47.

Gece, G. (2008). Corros. Sci. 50, 2981-2992.

Giraudon, R. (1972). Fr. Patent 2108834.

Giraudon, R. (1973). Chem. Abstr. 79, 32040.

Gududuru, V., Hurth, E., Dalton, J. T. \& Miller, D. D. (2004). Bioorg. Med. Chem. Lett. 14, 5289-5293.

Gupta, R. \& Chaudhary, R. P. (2013). Phosphorus Sulfur Silicon, 188, 1296-1304.

Hassan, A. A., Mohamed, S. K., Mohamed, N. K., El-Shaieb, K. M. A., Abdel-Aziz, A. T., Mague, J. T. \& Akkurt, M. (2017). J. Heterocycl. Chem. 54, 2043-2053.

Holmes, C., Chinn, J. P., Look, G. C., Gordon, E. M. \& Gallop, M. A. (1995). J. Org. Chem. 60, 7328-7333.

Idouhli, R., N'Ait Ousidi, A., Koumya, Y., Abouelfida, A., Benyaich, A., Auhmani, A. \& Ait Itto, M. Y. (2018a). Int. J. Corros. pp. 1-15.

Idouhli, R., Oukhrib, A., Koumya, Y., Abouelfida, A., Benyaich, A. \& Benharref, A. (2018b). Corros Rev. 36, 373-384.

Klapper, H. S., Goellner, J., Burkert, A. \& Hegn, A. (2013). Corros. Sci. 75, 239-247.
Lebrini, M., Lagrene, M., Traisnel, M., Gengembre, L., Vezin, H. \& Bentiss, F. (2007). Appl. Surf. Sci. 253, 9267-9276.

Lee, C., Yang, W. \& Parr, R. G. (1988). Phys. Rev. B, 37, 785-789.

Li, L., Zhang, X., Lei, J., He, J., Zhang, S. \& Pan, F. (2012). Corros. Sci. 63, 82-90.

Li, Z., Dong, Q., Li, Y., Xu, B., Deng, M., Pei, J., Zhang, J., Chen, F., Wen, S., Gao, Y. \& Tian, W. (2011). J. Mater. Chem. 21, 2159-2168. Lukovits, I., Kálmán, E. \& Zucchi, F. (2001). Corrosion, 57, 3-8.

Maclean, D., Holden, F., Davis, A. M., Scheuerman, R. A., Yanofsky, S., Holmes, C. P., Fitch, W. L., Tsutsui, K., Barrett, R. W. \& Gallop, M. A. (2004). J. Comb. Chem. 6, 196-206.

Mague, J. T., Akkurt, M., Mohamed, S. K., Hassan, A. A. \& Albayati, M. R. (2014). Acta Cryst. E70, o436-0437.

Misra, N. C. \& Patnayak, K. K. (1971). Indian J. Appl. Chem. 34, 148155.

Mourya, P., Banerjee, S., Rastogi, R. B. \& Singh, M. M. (2013). ACS Ind. Eng. Chem. Res. 52, 12733-12747.

Nagar, S., Singh, H. H., Sinha, J. N. \& Parmar, S. S. (1973). J. Med. Chem. 16, 178-180.

N'ait Ousidi, A., Ait Itto, M. Y., Auhmani, A., Riahi, A., Auhmani, A. \& Daran, J.-C. (2017). Acta Cryst. E73, 296-299.

Ottana, R., Carotti, S., Maccari, R., Landini, I., Chiricosta, G., Caciagli, B., Vigorita, M. G. \& Mini, E. (2005a). Bioorg. Med. Chem. Lett. 15, 3930-3933.

Ottana, R., Maccari, R., Barreca, M. L., Bruno, G., Rotondo, A., Rossi, A., Chiricosta, G., Di Paola, R., Sautebin, L., Cuzzocread, S. \& Vigorita, M. G. (2005b). Bioorg. Med. Chem. 13, 4243-4252.

Ottana, R., Mazzon, E., Dugo, L., Monforte, F., Maccari, R., Sautebin, L., De Luca, G., Vigorita, M. G., Alcaro, S., Ortuso, F., Caputi, A. P. \& Cuzzocrea, S. (2002). Eur. J. Pharmacol. 448, 71-80.

Ourhriss, N., Giorgi, M., Mazoir, N. \& Benharref, A. (2005). Acta Cryst. C61, o699-o701.

Parmar, S. S., Dwivedi, C., Chaudhari, A. \& Gupta, T. K. (1972). J. Med. Chem. 15, 99-101.

Parsons, S., Flack, H. D. \& Wagner, T. (2013). Acta Cryst. B69, 249 259.

Patel, N. S., Jauhariand, S., Mehta, G. N., Al-Deyab, S. S., Warad, I. \& Hammouti, B. (2013). Int. J. Electrochem. Sci. 8, 2635-2655.

Pyo, H., Choy, H., Amorino, G. P., Kim, J. S., Cao, Q., Hercules, S. K. \& DuBois, R. N. (2001). Clin. Cancer Res. 7, 2998-3005.

Ramachandran, R., Rani, M. \& Kabilan, S. (2009). Acta Cryst. E65, 0584.

Rawal, R. K., Prabhakar, Y. S., Katti, S. B. \& De Clercq, E. (2005). Bioorg. Med. Chem. 13, 6771-6776.

Sheldrick, G. M. (2008). Acta Cryst. A64, 112-122.

Sheldrick, G. M. (2015). Acta Cryst. C71, 3-8.

Shyam, R. \& Tiwari, I. C. (1977). Bull. Chem. Soc. Jpn, 50, 514-516.

Singh, A. \& Chaudhary, R. S. (1996). Br. Corros. J. 31, 300-304.

Singh, S. P., Parmar, S. S., Raman, K. \& Stenberg, V. I. (1981). Chem. Rev. 81, 175-203.

Srivastava, T., Gaikwad, A. K., Haq, W., Sinha, S. \& Katti, S. B. (2005). Arkivoc, ii, 120-130.

Suzuki, Y., Akima, M. \& Tamura, K. (1999). Gen. Pharmacol. 32, 5763.

Vicini, P., Geronikaki, A., Anastasia, K., Incertia, M. \& Zania, F. (2006). Bioorg. Med. Chem. 14, 3859-3864.

Vigorita, M. G., Ottana, R., Monforte, F., Maccari, R., Monforte, M. T., Trovato, A., Taviano, M. F., Miceli, N., De Luca, G., Alcaro, S. \& Ortuso, F. (2003). Bioorg. Med. Chem. 11, 999-1006.

Zubenky, V. G., Ladnaya, L. Y., Turkevich, N. M. \& Tatchinkapustyak, S. M. (1974). Farm. Zh. 29, 78.

Zubenky, V. G., Ladnaya, L. Y., Turkevich, N. M. \& Tatchinkapustyak, S. M. (1975). Chem. Abstr. 82, 667. 


\section{supporting information}

Hemisynthesis, crystal structure and inhibitory effect of sesquiterpenic thiosemicarbazones and thiazolidin-4-ones on the corrosion behaviour of stainless steel in $1 \mathrm{M} \mathrm{H}_{2} \mathrm{SO}_{4}$ solution

Abdoullah Bimoussa, Yassine Koumya, Abdesselam Abouelfida, Moulay Youssef Ait Itto, Abdelaziz Benyaich, Olivier Mentre, El Mostafa Ketatni, Aziz Auhmani and Abdelwahed Auhmani

Computing details

Data collection: DUO in APEX2 (Bruker, 2012); cell refinement: SAINT (Bruker, 2012); data reduction: SAINT (Bruker, 2012); program(s) used to solve structure: SHELXS2014 (Sheldrick, 2008); program(s) used to refine structure: SHELXL2014 (Sheldrick, 2015); molecular graphics: ORTEP-3 for Windows (Farrugia, 2012) and DIAMOND (Brandenburg \& Putz, 2012); software used to prepare material for publication: SHELXL2014 (Sheldrick, 2015).

Ethyl 2-\{(Z)-2-\{(Z)-[(1aR,5aR,9aS)-1,1-dichloro-1a,5,5,7-tetramethyl-1a,2,3,4,5,5a,8,9-octahydro-1Hbenzo[a]cyclopropa[b][7]annulen-8-ylidene]hydrazono\}-4-oxothiazolidin-3-yl)acetate

Crystal data

$\mathrm{C}_{23} \mathrm{H}_{31} \mathrm{Cl}_{2} \mathrm{~N}_{3} \mathrm{O}_{3} \mathrm{~S}$

$M_{r}=500.47$

Orthorhombic, $P 22_{1} 2_{1}$

$a=10.2769(7) \AA$

$b=12.2445(7) \AA$

$c=20.0804(13) \AA$

$V=2526.8(3) \AA^{3}$

$Z=4$

$F(000)=1056$

Data collection

Bruker DUO APEXII CCD diffractometer

$\varphi$ and $\omega$ scans

Absorption correction: multi-scan

(SADABS; Bruker, 2012)

$T_{\min }=0.710, T_{\max }=0.746$

58280 measured reflections

Refinement

Refinement on $F^{2}$

Least-squares matrix: full

$R\left[F^{2}>2 \sigma\left(F^{2}\right)\right]=0.038$

$w R\left(F^{2}\right)=0.089$
$D_{\mathrm{x}}=1.316 \mathrm{Mg} \mathrm{m}^{-3}$

Mo $K \alpha$ radiation, $\lambda=0.71073 \AA$

Cell parameters from 5789 reflections

$\theta=2.0-27.5^{\circ}$

$\mu=0.37 \mathrm{~mm}^{-1}$

$T=299 \mathrm{~K}$

Block, colourless

$0.34 \times 0.21 \times 0.11 \mathrm{~mm}$

5789 independent reflections

4306 reflections with $I>2 \sigma(I)$

$R_{\text {int }}=0.056$

$\theta_{\text {max }}=27.5^{\circ}, \theta_{\min }=2.0^{\circ}$

$h=-13 \rightarrow 13$

$k=-15 \rightarrow 15$

$l=-25 \rightarrow 25$

$S=1.03$

5789 reflections

294 parameters

0 restraints 
Hydrogen site location: inferred from neighbouring sites

$\mathrm{H}$-atom parameters constrained

$w=1 /\left[\sigma^{2}\left(F_{\mathrm{o}}^{2}\right)+(0.0393 P)^{2}+0.3269 P\right]$

where $P=\left(F_{\mathrm{o}}^{2}+2 F_{\mathrm{c}}^{2}\right) / 3$

$(\Delta / \sigma)_{\max }<0.001$
$\Delta \rho_{\max }=0.26$ e $\AA^{-3}$

$\Delta \rho_{\min }=-0.19$ e $\AA^{-3}$

Absolute structure: Flack $x$ determined using 1538 quotients $[(\mathrm{I}+)-(\mathrm{I}-)] /[(\mathrm{I}+)+(\mathrm{I}-)]$ (Parsons et al., 2013)

Absolute structure parameter: -0.04 (2)

\section{Special details}

Geometry. All esds (except the esd in the dihedral angle between two 1.s. planes) are estimated using the full covariance matrix. The cell esds are taken into account individually in the estimation of esds in distances, angles and torsion angles; correlations between esds in cell parameters are only used when they are defined by crystal symmetry. An approximate (isotropic) treatment of cell esds is used for estimating esds involving 1.s. planes.

Fractional atomic coordinates and isotropic or equivalent isotropic displacement parameters $\left(\AA^{2}\right)$

\begin{tabular}{|c|c|c|c|c|}
\hline & $x$ & $y$ & $z$ & $U_{\text {iso }} * / U_{\text {eq }}$ \\
\hline $\mathrm{C} 11$ & $0.91689(9)$ & $0.40874(6)$ & $0.28176(4)$ & $0.0521(2)$ \\
\hline $\mathrm{Cl} 2$ & $0.92163(8)$ & $0.64247(6)$ & $0.28263(4)$ & $0.0456(2)$ \\
\hline $\mathrm{S} 1^{\prime}$ & $0.41368(9)$ & $0.18868(7)$ & $0.16736(5)$ & $0.0572(3)$ \\
\hline $\mathrm{O} 1$ & $0.5447(3)$ & $-0.10510(19)$ & $0.14607(15)$ & $0.0719(8)$ \\
\hline $\mathrm{O} 2$ & $0.7293(3)$ & $0.0766(2)$ & $0.02640(14)$ & $0.0716(8)$ \\
\hline $\mathrm{O} 3$ & $0.9255(3)$ & $0.0866(3)$ & $0.07238(13)$ & $0.0816(9)$ \\
\hline N1 & $0.6044(2)$ & $0.3561(2)$ & $0.15782(13)$ & $0.0447(6)$ \\
\hline $\mathrm{N} 2$ & $0.6657(3)$ & $0.2530(2)$ & $0.15405(14)$ & $0.0441(7)$ \\
\hline N3' & $0.6216(2)$ & 0.06903 (19) & $0.15379(14)$ & $0.0447(7)$ \\
\hline $\mathrm{C} 1$ & $0.9428(3)$ & $0.5258(2)$ & $0.23193(14)$ & $0.0334(6)$ \\
\hline $\mathrm{C} 1 \mathrm{~A}$ & $1.0446(3)$ & $0.5220(2)$ & $0.17788(15)$ & $0.0341(7)$ \\
\hline $\mathrm{C} 2$ & $1.1211(3)$ & $0.6249(2)$ & $0.16433(16)$ & $0.0418(7)$ \\
\hline $\mathrm{H} 2 \mathrm{~A}$ & 1.2050 & 0.6198 & 0.1863 & $0.050^{*}$ \\
\hline $\mathrm{H} 2 \mathrm{~B}$ & 1.0751 & 0.6868 & 0.1831 & $0.050^{*}$ \\
\hline $\mathrm{C} 3$ & $1.1421(3)$ & 0.6439 & 0.08995 (18) & $0.0538(9)$ \\
\hline $\mathrm{H} 3 \mathrm{~A}$ & 1.2185 & 0.6032 & 0.0761 & $0.065^{*}$ \\
\hline H3B & 1.1605 & 0.7208 & 0.0830 & $0.065^{*}$ \\
\hline $\mathrm{C} 4$ & $1.0282(3)$ & $0.6115(3)$ & $0.04491(17)$ & $0.0509(9)$ \\
\hline $\mathrm{H} 4 \mathrm{~A}$ & 1.0515 & 0.6310 & -0.0004 & $0.061 *$ \\
\hline H4B & 1.0207 & 0.5326 & 0.0464 & $0.061 *$ \\
\hline $\mathrm{C} 5$ & 0.8934 & $0.6590(2)$ & $0.05887(15)$ & $0.0425(8)$ \\
\hline C5A & 0.8460 & $0.6323(2)$ & $0.13161(14)$ & $0.0338(7)$ \\
\hline H5A & 0.8799 & 0.6908 & 0.1600 & $0.041 *$ \\
\hline C6 & 0.7006 & $0.6342(3)$ & $0.13993(15)$ & $0.0406(7)$ \\
\hline H6 & 0.6597 & 0.7019 & 0.1379 & $0.049 *$ \\
\hline $\mathrm{C} 7$ & $0.6253(3)$ & $0.5472(2)$ & $0.14991(15)$ & $0.0387(7)$ \\
\hline $\mathrm{C} 8$ & $0.6826(3)$ & $0.4371(2)$ & $0.14911(15)$ & $0.0357(7)$ \\
\hline C9 & $0.8265(3)$ & $0.4258(2)$ & 0.13597 (16) & $0.0361(7)$ \\
\hline H9A & 0.8412 & 0.4166 & 0.0886 & $0.043^{*}$ \\
\hline H9B & 0.8594 & 0.3614 & 0.1585 & $0.043^{*}$ \\
\hline C9A & 0.8990 & $0.5258(2)$ & $0.16040(13)$ & $0.0300(6)$ \\
\hline C10 & $1.1226(3)$ & $0.4187(2)$ & $0.16751(19)$ & $0.0466(8)$ \\
\hline $\mathrm{H} 10 \mathrm{~A}$ & 1.0659 & 0.3566 & 0.1703 & $0.070^{*}$ \\
\hline
\end{tabular}




\begin{tabular}{|c|c|c|c|c|}
\hline H10B & 1.1885 & 0.4134 & 0.2013 & $0.070^{*}$ \\
\hline $\mathrm{H} 10 \mathrm{C}$ & 1.1630 & 0.4206 & 0.1244 & $0.070^{*}$ \\
\hline $\mathrm{C} 11$ & $0.8944(4)$ & $0.7841(3)$ & $0.05106(19)$ & $0.0587(10)$ \\
\hline H11A & 0.9255 & 0.8029 & 0.0074 & $0.088^{*}$ \\
\hline H11B & 0.9507 & 0.8156 & 0.0840 & $0.088^{*}$ \\
\hline $\mathrm{H} 11 \mathrm{C}$ & 0.8078 & 0.8119 & 0.0568 & $0.088^{*}$ \\
\hline C12 & $0.8010(4)$ & $0.6128(3)$ & $0.00546(17)$ & $0.0591(10)$ \\
\hline $\mathrm{H} 12 \mathrm{~A}$ & 0.8294 & 0.6361 & -0.0378 & $0.089^{*}$ \\
\hline H12B & 0.7143 & 0.6389 & 0.0134 & $0.089^{*}$ \\
\hline $\mathrm{H} 12 \mathrm{C}$ & 0.8017 & 0.5344 & 0.0075 & $0.089 *$ \\
\hline $\mathrm{C} 13$ & $0.4803(3)$ & $0.5579(3)$ & 0.1594 (2) & $0.0581(10)$ \\
\hline $\mathrm{H} 13 \mathrm{~A}$ & 0.4360 & 0.5206 & 0.1240 & $0.087^{*}$ \\
\hline H13B & 0.4566 & 0.6338 & 0.1589 & $0.087^{*}$ \\
\hline H13C & 0.4560 & 0.5263 & 0.2013 & $0.087 *$ \\
\hline $\mathrm{C} 2^{\prime}$ & $0.5817(3)$ & $0.1767(2)$ & $0.15774(15)$ & $0.0414(7)$ \\
\hline $\mathrm{C} 4^{\prime}$ & $0.5249(3)$ & $-0.0091(3)$ & $0.15382(17)$ & $0.0501(9)$ \\
\hline $\mathrm{C}^{\prime}$ & $0.3940(3)$ & $0.0420(3)$ & $0.1651(2)$ & $0.0565(9)$ \\
\hline H5'A & 0.3576 & 0.0164 & 0.2068 & $0.068^{*}$ \\
\hline $\mathrm{H} 5^{\prime} \mathrm{B}$ & 0.3351 & 0.0218 & 0.1294 & $0.068^{*}$ \\
\hline $\mathrm{C} 6^{\prime}$ & $0.7568(3)$ & $0.0426(3)$ & $0.14311(17)$ & $0.0479(8)$ \\
\hline H6'A & 0.7701 & -0.0348 & 0.1508 & $0.057 *$ \\
\hline H6'B & 0.8099 & 0.0826 & 0.1748 & $0.057^{*}$ \\
\hline$C 7^{\prime}$ & $0.7990(4)$ & $0.0707(3)$ & $0.07342(19)$ & $0.0493(9)$ \\
\hline$C 8^{\prime}$ & $0.9852(5)$ & $0.1165(6)$ & $0.0093(2)$ & 0.1041 (19) \\
\hline H8'A & 1.0096 & 0.0512 & -0.0151 & $0.125^{*}$ \\
\hline $\mathrm{H} 8^{\prime} \mathrm{B}$ & 0.9239 & 0.1576 & -0.0176 & $0.125^{*}$ \\
\hline $\mathrm{C} 9^{\prime}$ & $1.0974(7)$ & $0.1811(5)$ & $0.0221(3)$ & $0.133(3)$ \\
\hline $\mathrm{H}^{\prime} \mathrm{A}$ & 1.1409 & 0.1969 & -0.0191 & $0.199 *$ \\
\hline H9'B & 1.1553 & 0.1417 & 0.0510 & $0.199 *$ \\
\hline $\mathrm{H}^{\prime} \mathrm{C}$ & 1.0718 & 0.2481 & 0.0431 & $0.199 *$ \\
\hline
\end{tabular}

Atomic displacement parameters $\left(\AA^{2}\right)$

\begin{tabular}{lllllll}
\hline & $U^{11}$ & $U^{22}$ & $U^{33}$ & $U^{12}$ & $U^{13}$ & $U^{23}$ \\
\hline C11 & $0.0539(5)$ & $0.0422(4)$ & $0.0601(5)$ & $0.0043(4)$ & $0.0065(5)$ & $0.0198(4)$ \\
C12 & $0.0503(5)$ & $0.0425(4)$ & $0.0441(4)$ & $0.0020(4)$ & $-0.0012(4)$ & $-0.0076(3)$ \\
S1' & $0.0366(5)$ & $0.0501(5)$ & $0.0849(7)$ & $-0.0068(4)$ & $0.0104(5)$ & $-0.0062(4)$ \\
O1 & $0.076(2)$ & $0.0378(13)$ & $0.102(2)$ & $-0.0106(12)$ & $0.0121(16)$ & $-0.0047(13)$ \\
O2 & $0.0620(19)$ & $0.097(2)$ & $0.0559(17)$ & $-0.0111(16)$ & $-0.0092(16)$ & $-0.0069(14)$ \\
O3 & $0.0451(18)$ & $0.150(3)$ & $0.0499(16)$ & $-0.0113(19)$ & $0.0077(14)$ & $0.0047(16)$ \\
N1 & $0.0343(15)$ & $0.0404(13)$ & $0.0595(17)$ & $-0.0021(13)$ & $0.0024(13)$ & $-0.0069(12)$ \\
N2 & $0.0354(15)$ & $0.0366(14)$ & $0.0602(18)$ & $-0.0060(12)$ & $0.0039(14)$ & $-0.0043(12)$ \\
N3' & $0.0388(17)$ & $0.0356(13)$ & $0.0597(18)$ & $-0.0024(11)$ & $0.0036(14)$ & $-0.0034(12)$ \\
C1 & $0.0333(17)$ & $0.0264(13)$ & $0.0404(16)$ & $0.0001(13)$ & $-0.0001(13)$ & $0.0027(12)$ \\
C1A & $0.0274(16)$ & $0.0292(13)$ & $0.0456(17)$ & $0.0018(12)$ & $0.0017(13)$ & $0.0024(13)$ \\
C2 & $0.0284(17)$ & $0.0387(16)$ & $0.058(2)$ & $-0.0035(13)$ & $0.0029(15)$ & $0.0018(14)$ \\
C3 & $0.041(2)$ & $0.056(2)$ & $0.065(2)$ & $-0.0024(17)$ & $0.0117(18)$ & $0.0132(18)$ \\
C4 & $0.052(2)$ & $0.053(2)$ & $0.047(2)$ & $0.0064(17)$ & $0.0104(17)$ & $0.0089(16)$
\end{tabular}




\begin{tabular}{|c|c|c|c|c|c|c|}
\hline $\mathrm{C} 5$ & $0.049(2)$ & $0.0374(16)$ & $0.0415(18)$ & $0.0039(15)$ & $-0.0017(16)$ & $0.0042(12)$ \\
\hline $\mathrm{C} 5 \mathrm{~A}$ & $0.0336(17)$ & $0.0287(14)$ & $0.0391(16)$ & 0.0035 (13) & $-0.0022(13)$ & $0.0010(12)$ \\
\hline C6 & $0.0351(18)$ & $0.0371(16)$ & 0.0496 (19) & $0.0112(14)$ & $-0.0046(15)$ & $0.0006(14)$ \\
\hline $\mathrm{C} 7$ & $0.0298(17)$ & $0.0434(17)$ & $0.0429(18)$ & $0.0051(13)$ & $-0.0020(14)$ & $-0.0071(13)$ \\
\hline $\mathrm{C} 8$ & $0.0289(17)$ & $0.0377(16)$ & $0.0406(18)$ & $-0.0004(13)$ & $-0.0006(14)$ & $-0.0046(13)$ \\
\hline C9 & $0.0288(17)$ & $0.0292(14)$ & 0.0501 (19) & $0.0032(12)$ & $0.0006(14)$ & $-0.0034(13)$ \\
\hline C9A & $0.0245(15)$ & $0.0264(12)$ & $0.0392(15)$ & $0.0025(12)$ & 0.0007 (13) & $-0.0014(12)$ \\
\hline $\mathrm{C} 10$ & $0.0324(18)$ & 0.0387 (16) & 0.069 (2) & $0.0074(14)$ & $0.0046(17)$ & $0.0030(15)$ \\
\hline C11 & $0.073(3)$ & 0.0444 (19) & 0.059 (2) & $0.003(2)$ & $-0.004(2)$ & $0.0173(15)$ \\
\hline $\mathrm{C} 12$ & 0.069 (3) & $0.061(2)$ & $0.048(2)$ & $0.007(2)$ & $-0.0091(19)$ & 0.0008 (17) \\
\hline $\mathrm{C} 13$ & $0.033(2)$ & $0.066(2)$ & 0.075 & $0.0113(17)$ & $-0.0009(19)$ & $-0.011(2)$ \\
\hline $\mathrm{C} 2^{\prime}$ & $0.0361(17)$ & $0.0424(16)$ & $0.0456(18)$ & $-0.0061(15)$ & $0.0042(16)$ & $-0.0044(13)$ \\
\hline $\mathrm{C} 4^{\prime}$ & $0.051(2)$ & $0.046(2)$ & $0.054(2)$ & $-0.0124(16)$ & $0.0059(17)$ & $0.0001(16)$ \\
\hline $\mathrm{C}^{\prime}$ & $0.044(2)$ & $0.054(2)$ & $0.071(2)$ & $-0.0187(17)$ & $0.0089(19)$ & $-0.0073(17)$ \\
\hline $\mathrm{C} 6^{\prime}$ & $0.040(2)$ & 0.0479 (19) & $0.056(2)$ & $0.0009(16)$ & $0.0027(16)$ & $-0.0011(16)$ \\
\hline$C 7^{\prime}$ & $0.043(2)$ & 0.051 (2) & $0.053(2)$ & $-0.0010(17)$ & $0.0023(19)$ & $-0.0078(16)$ \\
\hline C $8^{\prime}$ & $0.069(3)$ & 0.194 (6) & 0.049 (3) & $-0.023(4)$ & $0.021(2)$ & $-0.005(3)$ \\
\hline$C 9^{\prime}$ & $0.171(7)$ & $0.148(5)$ & $0.079(4)$ & $-0.076(5)$ & $0.042(4)$ & -0.027 (3) \\
\hline
\end{tabular}

Geometric parameters $\left(\AA,{ }^{\circ}\right)$

\begin{tabular}{|c|c|c|c|}
\hline $\mathrm{C} 11-\mathrm{C} 1$ & $1.768(3)$ & $\mathrm{C} 5 \mathrm{~A}-\mathrm{H} 5 \mathrm{~A}$ & 0.9800 \\
\hline $\mathrm{Cl} 2-\mathrm{C} 1$ & $1.768(3)$ & $\mathrm{C} 6-\mathrm{C} 7$ & $1.332(4)$ \\
\hline $\mathrm{S} 1^{\prime}-\mathrm{C} 2^{\prime}$ & $1.744(3)$ & $\mathrm{C} 6-\mathrm{H} 6$ & 0.9300 \\
\hline $\mathrm{S} 1^{\prime}-\mathrm{C} 5^{\prime}$ & $1.808(3)$ & $\mathrm{C} 7-\mathrm{C} 8$ & $1.472(4)$ \\
\hline $\mathrm{O} 1-\mathrm{C}^{\prime}$ & $1.203(4)$ & $\mathrm{C} 7-\mathrm{C} 13$ & $1.508(5)$ \\
\hline $\mathrm{O} 2-\mathrm{C}^{\prime}$ & $1.188(4)$ & $\mathrm{C} 8-\mathrm{C} 9$ & $1.509(4)$ \\
\hline $\mathrm{O} 3-\mathrm{C}^{\prime}$ & $1.315(5)$ & $\mathrm{C} 9-\mathrm{C} 9 \mathrm{~A}$ & $1.515(4)$ \\
\hline $\mathrm{O} 3-\mathrm{C}^{\prime}$ & $1.455(5)$ & $\mathrm{C} 9-\mathrm{H} 9 \mathrm{~A}$ & 0.9700 \\
\hline $\mathrm{N} 1-\mathrm{C} 8$ & $1.288(4)$ & C9-H9B & 0.9700 \\
\hline $\mathrm{N} 1-\mathrm{N} 2$ & $1.413(3)$ & $\mathrm{C} 10-\mathrm{H} 10 \mathrm{~A}$ & 0.9600 \\
\hline $\mathrm{N} 2-\mathrm{C} 2^{\prime}$ & $1.274(4)$ & $\mathrm{C} 10-\mathrm{H} 10 \mathrm{~B}$ & 0.9600 \\
\hline $\mathrm{N} 3^{\prime}-\mathrm{C} 4^{\prime}$ & $1.380(4)$ & $\mathrm{C} 10-\mathrm{H} 10 \mathrm{C}$ & 0.9600 \\
\hline $\mathrm{N} 3^{\prime}-\mathrm{C} 2^{\prime}$ & $1.383(4)$ & C11-H11A & 0.9600 \\
\hline $\mathrm{N} 3^{\prime}-\mathrm{C}^{\prime}$ & $1.442(4)$ & $\mathrm{C} 11-\mathrm{H} 11 \mathrm{~B}$ & 0.9600 \\
\hline $\mathrm{C} 1-\mathrm{C} 9 \mathrm{~A}$ & $1.505(4)$ & $\mathrm{C} 11-\mathrm{H} 11 \mathrm{C}$ & 0.9600 \\
\hline $\mathrm{C} 1-\mathrm{C} 1 \mathrm{~A}$ & $1.508(4)$ & $\mathrm{C} 12-\mathrm{H} 12 \mathrm{~A}$ & 0.9600 \\
\hline $\mathrm{C} 1 \mathrm{~A}-\mathrm{C} 2$ & 1.509 (4) & $\mathrm{C} 12-\mathrm{H} 12 \mathrm{~B}$ & 0.9600 \\
\hline $\mathrm{C} 1 \mathrm{~A}-\mathrm{C} 10$ & $1.512(4)$ & $\mathrm{C} 12-\mathrm{H} 12 \mathrm{C}$ & 0.9600 \\
\hline $\mathrm{C} 1 \mathrm{~A}-\mathrm{C} 9 \mathrm{~A}$ & $1.538(4)$ & $\mathrm{C} 13-\mathrm{H} 13 \mathrm{~A}$ & 0.9600 \\
\hline $\mathrm{C} 2-\mathrm{C} 3$ & $1.527(5)$ & $\mathrm{C} 13-\mathrm{H} 13 \mathrm{~B}$ & 0.9600 \\
\hline $\mathrm{C} 2-\mathrm{H} 2 \mathrm{~A}$ & 0.9700 & $\mathrm{C} 13-\mathrm{H} 13 \mathrm{C}$ & 0.9600 \\
\hline $\mathrm{C} 2-\mathrm{H} 2 \mathrm{~B}$ & 0.9700 & $\mathrm{C} 4^{\prime}-\mathrm{C} 5^{\prime}$ & $1.501(5)$ \\
\hline $\mathrm{C} 3-\mathrm{C} 4$ & $1.532(5)$ & $\mathrm{C} 5^{\prime}-\mathrm{H} 5^{\prime} \mathrm{A}$ & 0.9700 \\
\hline $\mathrm{C} 3-\mathrm{H} 3 \mathrm{~A}$ & 0.9700 & $\mathrm{C} 5^{\prime}-\mathrm{H} 5^{\prime} \mathrm{B}$ & 0.9700 \\
\hline $\mathrm{C} 3-\mathrm{H} 3 \mathrm{~B}$ & 0.9700 & $\mathrm{C} 6^{\prime}-\mathrm{C} 7^{\prime}$ & $1.505(5)$ \\
\hline $\mathrm{C} 4-\mathrm{C} 5$ & $1.529(5)$ & $\mathrm{C} 6^{\prime}-\mathrm{H} 6^{\prime} \mathrm{A}$ & 0.9700 \\
\hline $\mathrm{C} 4-\mathrm{H} 4 \mathrm{~A}$ & 0.9700 & $\mathrm{C} 6^{\prime}-\mathrm{H} 6^{\prime} \mathrm{B}$ & 0.9700 \\
\hline
\end{tabular}




\begin{tabular}{|c|c|c|c|}
\hline $\mathrm{C} 4-\mathrm{H} 4 \mathrm{~B}$ & 0.9700 & $\mathrm{C} 8^{\prime}-\mathrm{C} 9^{\prime}$ & $1.421(7)$ \\
\hline $\mathrm{C} 5-\mathrm{C} 11$ & $1.539(4)$ & $\mathrm{C} 8^{\prime}-\mathrm{H} 8^{\prime} \mathrm{A}$ & 0.9700 \\
\hline $\mathrm{C} 5-\mathrm{C} 12$ & $1.540(5)$ & $\mathrm{C} 8^{\prime}-\mathrm{H} 8^{\prime} \mathrm{B}$ & 0.9700 \\
\hline $\mathrm{C} 5-\mathrm{C} 5 \mathrm{~A}$ & $1.574(4)$ & $\mathrm{C} 9^{\prime}-\mathrm{H} 9^{\prime} \mathrm{A}$ & 0.9600 \\
\hline $\mathrm{C} 5 \mathrm{~A}-\mathrm{C} 6$ & $1.504(4)$ & $\mathrm{C} 9^{\prime}-\mathrm{H} 9^{\prime} \mathrm{B}$ & 0.9600 \\
\hline $\mathrm{C} 5 \mathrm{~A}-\mathrm{C} 9 \mathrm{~A}$ & $1.527(4)$ & $\mathrm{C} 9^{\prime}-\mathrm{H} 9^{\prime} \mathrm{C}$ & 0.9600 \\
\hline $\mathrm{C} 2^{\prime}-\mathrm{S} 1^{\prime}-\mathrm{C} 5^{\prime}$ & $91.40(15)$ & $\mathrm{C} 1-\mathrm{C} 9 \mathrm{~A}-\mathrm{C} 9$ & $117.1(2)$ \\
\hline $\mathrm{C}^{\prime}-\mathrm{O} 3-\mathrm{C} 8^{\prime}$ & $117.9(3)$ & $\mathrm{C} 1-\mathrm{C} 9 \mathrm{~A}-\mathrm{C} 5 \mathrm{~A}$ & $117.9(2)$ \\
\hline $\mathrm{C} 8-\mathrm{N} 1-\mathrm{N} 2$ & $113.7(2)$ & $\mathrm{C} 9-\mathrm{C} 9 \mathrm{~A}-\mathrm{C} 5 \mathrm{~A}$ & $113.1(2)$ \\
\hline $\mathrm{C} 2{ }^{\prime}-\mathrm{N} 2-\mathrm{N} 1$ & $110.5(3)$ & $\mathrm{C} 1-\mathrm{C} 9 \mathrm{~A}-\mathrm{C} 1 \mathrm{~A}$ & $59.40(19)$ \\
\hline $\mathrm{C} 4^{\prime}-\mathrm{N} 3^{\prime}-\mathrm{C} 2^{\prime}$ & $116.6(3)$ & $\mathrm{C} 9-\mathrm{C} 9 \mathrm{~A}-\mathrm{C} 1 \mathrm{~A}$ & $121.9(2)$ \\
\hline $\mathrm{C} 4^{\prime}-\mathrm{N} 3^{\prime}-\mathrm{C} 6^{\prime}$ & $122.6(3)$ & $\mathrm{C} 5 \mathrm{~A}-\mathrm{C} 9 \mathrm{~A}-\mathrm{C} 1 \mathrm{~A}$ & $117.3(2)$ \\
\hline $\mathrm{C} 2^{\prime}-\mathrm{N} 3^{\prime}-\mathrm{C} 6^{\prime}$ & $120.5(3)$ & $\mathrm{C} 1 \mathrm{~A}-\mathrm{C} 10-\mathrm{H} 10 \mathrm{~A}$ & 109.5 \\
\hline $\mathrm{C} 9 \mathrm{~A}-\mathrm{C} 1-\mathrm{C} 1 \mathrm{~A}$ & $61.37(18)$ & $\mathrm{C} 1 \mathrm{~A}-\mathrm{C} 10-\mathrm{H} 10 \mathrm{~B}$ & 109.5 \\
\hline $\mathrm{C} 9 \mathrm{~A}-\mathrm{C} 1-\mathrm{Cl1}$ & $119.7(2)$ & $\mathrm{H} 10 \mathrm{~A}-\mathrm{C} 10-\mathrm{H} 10 \mathrm{~B}$ & 109.5 \\
\hline $\mathrm{C} 1 \mathrm{~A}-\mathrm{C} 1-\mathrm{C} 11$ & $119.2(2)$ & $\mathrm{C} 1 \mathrm{~A}-\mathrm{C} 10-\mathrm{H} 10 \mathrm{C}$ & 109.5 \\
\hline $\mathrm{C} 9 \mathrm{~A}-\mathrm{C} 1-\mathrm{Cl} 2$ & $120.84(19)$ & $\mathrm{H} 10 \mathrm{~A}-\mathrm{C} 10-\mathrm{H} 10 \mathrm{C}$ & 109.5 \\
\hline $\mathrm{C} 1 \mathrm{~A}-\mathrm{C} 1-\mathrm{Cl} 2$ & $121.6(2)$ & $\mathrm{H} 10 \mathrm{~B}-\mathrm{C} 10-\mathrm{H} 10 \mathrm{C}$ & 109.5 \\
\hline $\mathrm{C} 11-\mathrm{C} 1-\mathrm{Cl} 2$ & $108.09(15)$ & $\mathrm{C} 5-\mathrm{C} 11-\mathrm{H} 11 \mathrm{~A}$ & 109.5 \\
\hline $\mathrm{C} 1-\mathrm{C} 1 \mathrm{~A}-\mathrm{C} 2$ & $117.8(2)$ & $\mathrm{C} 5-\mathrm{C} 11-\mathrm{H} 11 \mathrm{~B}$ & 109.5 \\
\hline $\mathrm{C} 1-\mathrm{C} 1 \mathrm{~A}-\mathrm{C} 10$ & $119.5(2)$ & $\mathrm{H} 11 \mathrm{~A}-\mathrm{C} 11-\mathrm{H} 11 \mathrm{~B}$ & 109.5 \\
\hline $\mathrm{C} 2-\mathrm{C} 1 \mathrm{~A}-\mathrm{C} 10$ & $113.4(2)$ & $\mathrm{C} 5-\mathrm{C} 11-\mathrm{H} 11 \mathrm{C}$ & 109.5 \\
\hline $\mathrm{C} 1-\mathrm{C} 1 \mathrm{~A}-\mathrm{C} 9 \mathrm{~A}$ & $59.22(18)$ & $\mathrm{H} 11 \mathrm{~A}-\mathrm{C} 11-\mathrm{H} 11 \mathrm{C}$ & 109.5 \\
\hline $\mathrm{C} 2-\mathrm{C} 1 \mathrm{~A}-\mathrm{C} 9 \mathrm{~A}$ & $116.2(2)$ & $\mathrm{H} 11 \mathrm{~B}-\mathrm{C} 11-\mathrm{H} 11 \mathrm{C}$ & 109.5 \\
\hline $\mathrm{C} 10-\mathrm{C} 1 \mathrm{~A}-\mathrm{C} 9 \mathrm{~A}$ & $120.6(2)$ & $\mathrm{C} 5-\mathrm{C} 12-\mathrm{H} 12 \mathrm{~A}$ & 109.5 \\
\hline $\mathrm{C} 1 \mathrm{~A}-\mathrm{C} 2-\mathrm{C} 3$ & $112.2(3)$ & $\mathrm{C} 5-\mathrm{C} 12-\mathrm{H} 12 \mathrm{~B}$ & 109.5 \\
\hline $\mathrm{C} 1 \mathrm{~A}-\mathrm{C} 2-\mathrm{H} 2 \mathrm{~A}$ & 109.2 & $\mathrm{H} 12 \mathrm{~A}-\mathrm{C} 12-\mathrm{H} 12 \mathrm{~B}$ & 109.5 \\
\hline $\mathrm{C} 3-\mathrm{C} 2-\mathrm{H} 2 \mathrm{~A}$ & 109.2 & $\mathrm{C} 5-\mathrm{C} 12-\mathrm{H} 12 \mathrm{C}$ & 109.5 \\
\hline $\mathrm{C} 1 \mathrm{~A}-\mathrm{C} 2-\mathrm{H} 2 \mathrm{~B}$ & 109.2 & $\mathrm{H} 12 \mathrm{~A}-\mathrm{C} 12-\mathrm{H} 12 \mathrm{C}$ & 109.5 \\
\hline $\mathrm{C} 3-\mathrm{C} 2-\mathrm{H} 2 \mathrm{~B}$ & 109.2 & $\mathrm{H} 12 \mathrm{~B}-\mathrm{C} 12-\mathrm{H} 12 \mathrm{C}$ & 109.5 \\
\hline $\mathrm{H} 2 \mathrm{~A}-\mathrm{C} 2-\mathrm{H} 2 \mathrm{~B}$ & 107.9 & $\mathrm{C} 7-\mathrm{C} 13-\mathrm{H} 13 \mathrm{~A}$ & 109.5 \\
\hline $\mathrm{C} 2-\mathrm{C} 3-\mathrm{C} 4$ & $115.5(3)$ & $\mathrm{C} 7-\mathrm{C} 13-\mathrm{H} 13 \mathrm{~B}$ & 109.5 \\
\hline $\mathrm{C} 2-\mathrm{C} 3-\mathrm{H} 3 \mathrm{~A}$ & 108.4 & $\mathrm{H} 13 \mathrm{~A}-\mathrm{C} 13-\mathrm{H} 13 \mathrm{~B}$ & 109.5 \\
\hline $\mathrm{C} 4-\mathrm{C} 3-\mathrm{H} 3 \mathrm{~A}$ & 108.4 & $\mathrm{C} 7-\mathrm{C} 13-\mathrm{H} 13 \mathrm{C}$ & 109.5 \\
\hline $\mathrm{C} 2-\mathrm{C} 3-\mathrm{H} 3 \mathrm{~B}$ & 108.4 & $\mathrm{H} 13 \mathrm{~A}-\mathrm{C} 13-\mathrm{H} 13 \mathrm{C}$ & 109.5 \\
\hline $\mathrm{C} 4-\mathrm{C} 3-\mathrm{H} 3 \mathrm{~B}$ & 108.4 & $\mathrm{H} 13 \mathrm{~B}-\mathrm{C} 13-\mathrm{H} 13 \mathrm{C}$ & 109.5 \\
\hline $\mathrm{H} 3 \mathrm{~A}-\mathrm{C} 3-\mathrm{H} 3 \mathrm{~B}$ & 107.5 & $\mathrm{~N} 2-\mathrm{C} 2^{\prime}-\mathrm{N} 3^{\prime}$ & $119.6(3)$ \\
\hline $\mathrm{C} 5-\mathrm{C} 4-\mathrm{C} 3$ & $119.1(3)$ & $\mathrm{N} 2-\mathrm{C} 2^{\prime}-\mathrm{S} 1^{\prime}$ & $128.0(2)$ \\
\hline $\mathrm{C} 5-\mathrm{C} 4-\mathrm{H} 4 \mathrm{~A}$ & 107.6 & $\mathrm{~N} 3^{\prime}-\mathrm{C} 2^{\prime}-\mathrm{S} 1^{\prime}$ & $112.3(2)$ \\
\hline $\mathrm{C} 3-\mathrm{C} 4-\mathrm{H} 4 \mathrm{~A}$ & 107.6 & $\mathrm{O} 1-\mathrm{C}^{\prime}{ }^{\prime}-\mathrm{N} 3^{\prime}$ & $123.8(3)$ \\
\hline $\mathrm{C} 5-\mathrm{C} 4-\mathrm{H} 4 \mathrm{~B}$ & 107.6 & $\mathrm{O} 1-\mathrm{C} 4^{\prime}-\mathrm{C}^{\prime}$ & $125.3(3)$ \\
\hline $\mathrm{C} 3-\mathrm{C} 4-\mathrm{H} 4 \mathrm{~B}$ & 107.6 & $\mathrm{~N} 3^{\prime}-\mathrm{C} 4^{\prime}-\mathrm{C} 5^{\prime}$ & $110.9(3)$ \\
\hline $\mathrm{H} 4 \mathrm{~A}-\mathrm{C} 4-\mathrm{H} 4 \mathrm{~B}$ & 107.0 & $\mathrm{C} 4^{\prime}-\mathrm{C} 5^{\prime}-\mathrm{S} 1^{\prime}$ & $108.5(2)$ \\
\hline $\mathrm{C} 4-\mathrm{C} 5-\mathrm{C} 11$ & $110.7(3)$ & $\mathrm{C} 4^{\prime}-\mathrm{C} 5^{\prime}-\mathrm{H} 5^{\prime} \mathrm{A}$ & 110.0 \\
\hline $\mathrm{C} 4-\mathrm{C} 5-\mathrm{C} 12$ & $106.9(3)$ & $\mathrm{S} 1^{\prime}-\mathrm{C} 5^{\prime}-\mathrm{H} 5^{\prime} \mathrm{A}$ & 110.0 \\
\hline $\mathrm{C} 11-\mathrm{C} 5-\mathrm{C} 12$ & $107.4(3)$ & $\mathrm{C} 4^{\prime}-\mathrm{C} 5^{\prime}-\mathrm{H} 5^{\prime} \mathrm{B}$ & 110.0 \\
\hline $\mathrm{C} 4-\mathrm{C} 5-\mathrm{C} 5 \mathrm{~A}$ & $111.8(3)$ & $\mathrm{S} 1^{\prime}-\mathrm{C} 5^{\prime}-\mathrm{H} 5^{\prime} \mathrm{B}$ & 110.0 \\
\hline
\end{tabular}




$\begin{array}{ll}\mathrm{C} 11-\mathrm{C} 5-\mathrm{C} 5 \mathrm{~A} & 107.7(3) \\ \mathrm{C} 12-\mathrm{C} 5-\mathrm{C} 5 \mathrm{~A} & 112.3(3) \\ \mathrm{C} 6-\mathrm{C} 5 \mathrm{~A}-\mathrm{C} 9 \mathrm{~A} & 109.0(2) \\ \mathrm{C} 6-\mathrm{C} 5 \mathrm{~A}-\mathrm{C} 5 & 114.0(2) \\ \mathrm{C} 9 \mathrm{~A}-\mathrm{C} 5 \mathrm{~A}-\mathrm{C} 5 & 114.7(2) \\ \text { C6-C5A-H5A } & 106.1 \\ \text { C9A-C5A-H5A } & 106.1 \\ \text { C5-C5A-H5A } & 106.1 \\ \text { C7-C6-C5A } & 125.5(3) \\ \text { C7-C6-H6 } & 117.2 \\ \text { C5A-C6-H6 } & 117.2 \\ \text { C6-C7-C } & 119.9(3) \\ \text { C6-C7-C13 } & 121.6(3) \\ \text { C8-C7-C13 } & 118.5(3) \\ \text { N1-C8-C7 } & 117.0(3) \\ \text { N1-C8-C9 } & 124.4(3) \\ \text { C7-C } 8-\mathrm{C} 9 & 118.6(3) \\ \text { C8-C9-C9A } & 110.5(2) \\ \text { C8-C9-H9A } & 109.5 \\ \text { C9A-C9-H9A } & 109.5 \\ \text { C8-C9-H9B } & 109.5 \\ \text { C9A-C9-H9B } & 109.5 \\ \text { H9A-C9-H9B } & 108.1 \\ & \end{array}$

$\begin{array}{ll}\mathrm{H} 5^{\prime} \mathrm{A}-\mathrm{C} 5^{\prime}-\mathrm{H} 5^{\prime} \mathrm{B} & 108.4 \\ \mathrm{~N} 3^{\prime}-\mathrm{C} 6^{\prime}-\mathrm{C} 7^{\prime} & 111.4(3) \\ \mathrm{N} 3^{\prime}-\mathrm{C} 6^{\prime}-\mathrm{H} 6^{\prime} \mathrm{A} & 109.3 \\ \mathrm{C} 7^{\prime}-\mathrm{C} 6^{\prime}-\mathrm{H} 6^{\prime} \mathrm{A} & 109.3 \\ \mathrm{~N} 3^{\prime}-\mathrm{C} 6^{\prime}-\mathrm{H} 6^{\prime} \mathrm{B} & 109.3 \\ \mathrm{C} 7^{\prime}-\mathrm{C} 6^{\prime}-\mathrm{H} 6^{\prime} \mathrm{B} & 109.3 \\ \mathrm{H} 6^{\prime} \mathrm{A}-\mathrm{C} 6^{\prime}-\mathrm{H} 6^{\prime} \mathrm{B} & 108.0 \\ \mathrm{O} 2-\mathrm{C} 7^{\prime}-\mathrm{O} 3 & 125.1(4) \\ \mathrm{O} 2-\mathrm{C} 7^{\prime}-\mathrm{C} 6^{\prime} & 125.4(3) \\ \mathrm{O} 3-\mathrm{C} 7^{\prime}-\mathrm{C} 6^{\prime} & 109.5(3) \\ \mathrm{C} 9^{\prime}-\mathrm{C} 8^{\prime}-\mathrm{O} 3 & 108.9(4) \\ \mathrm{C} 9^{\prime}-\mathrm{C} 8^{\prime}-\mathrm{H} 8^{\prime} \mathrm{A} & 109.9 \\ \mathrm{O} 3-\mathrm{C} 8^{\prime}-\mathrm{H} 8^{\prime} \mathrm{A} & 109.9 \\ \mathrm{C} 9^{\prime}-\mathrm{C} 8^{\prime}-\mathrm{H} 8^{\prime} \mathrm{B} & 109.9 \\ \mathrm{O} 3-\mathrm{C} 8^{\prime}-\mathrm{H} 8^{\prime} \mathrm{B} & 109.9 \\ \mathrm{H} 8^{\prime} \mathrm{A}-\mathrm{C} 8^{\prime}-\mathrm{H} 8^{\prime} \mathrm{B} & 108.3 \\ \mathrm{C} 8^{\prime}-\mathrm{C} 9^{\prime}-\mathrm{H} 9^{\prime} \mathrm{A} & 109.5 \\ \mathrm{C} 8^{\prime}-\mathrm{C} 9^{\prime}-\mathrm{H} 9^{\prime} \mathrm{B} & 109.5 \\ \mathrm{H} 9^{\prime} \mathrm{A}-\mathrm{C} 9^{\prime}-\mathrm{H} 9^{\prime} \mathrm{B} & 109.5 \\ \mathrm{C} 8^{\prime}-\mathrm{C} 9^{\prime}-\mathrm{H} 9^{\prime} \mathrm{C} & 109.5 \\ \mathrm{H} 9^{\prime} \mathrm{A}-\mathrm{C} 9^{\prime}-\mathrm{H} 9^{\prime} \mathrm{C} & 109.5 \\ \mathrm{H} 9^{\prime} \mathrm{B}-\mathrm{C} 9^{\prime}-\mathrm{H} 9^{\prime} \mathrm{C} & 109.5 \\ \end{array}$

Hydrogen-bond geometry $\left(\AA,{ }^{\circ}\right)$

\begin{tabular}{lllll}
\hline$D-\mathrm{H} \cdots A$ & $D-\mathrm{H}$ & $\mathrm{H} \cdots A$ & $D \cdots A$ & $D-\mathrm{H} \cdots A$ \\
\hline $\mathrm{C} 10-\mathrm{H} 10 A \cdots \mathrm{Cl} 2^{\mathrm{i}}$ & 0.96 & 2.79 & $3.557(3)$ & 137 \\
$\mathrm{C} 2-\mathrm{H} 2 B \cdots \mathrm{Cl} 1^{\mathrm{ii}}$ & 0.97 & 2.81 & $3.661(3)$ & 147 \\
\hline
\end{tabular}

Symmetry codes: (i) $-x+2, y-1 / 2,-z+1 / 2$; (ii) $-x+2, y+1 / 2,-z+1 / 2$. 